\title{
La transmisión del Renacimiento cultural europeo en China. Un itinerario por las cartas de Alessandro Valignano (1575-1606)
}

\author{
Giuseppe Marino \\ Fudan University. Department of Spanish Studies \\ g.marino1982@gmail.com
}

Recepción: 26/08/2016, Aceptación: 25/01/2017, Publicación: 22/12/2017

\section{Resumen}

Alessandro Valignano es la clave para comprender la entrada de los jesuitas Michele Ruggieri y Matteo Ricci en el Imperio Ming. Gracias a su intuición y a la experiencia adquirida en la misión de Japón, Valignano tomó consciencia de lo importante que era aprender chino como condición sine qua non para acceder al interior del territorio oriental. El Visitador de la India, como así se conocía a Alessandro Valignano, fue la primera autoridad de la misión de China y el verdadero fundador de esta empresa. Sin embargo, la relación de este con la tierra de Confucio fue considerada simplemente desde un punto de vista general o, al contrario, tan específicamente que dicha concomitancia se redujo a unas pocas anécdotas históricas.

Este artículo tiene como objetivo localizar y considerar algunas fuentes europeas desconocidas hasta ahora sobre el padre Visitador de los jesuitas, así como sus opiniones y su organización de la misión de China durante los siglos XVI y XVII. Además, el estudio analiza las fuentes primarias, que van desde el primer contacto de Valignano con China hasta su gran objetivo de solicitar una embajada romana para el emperador chino (15881603), y su relación con Matteo Ricci.

Palabras clave

Valignano; China; misión; jesuitas; embajada

\footnotetext{
Abstract

The transmission of the European cultural Renaissance in China: A journey through the letters of Alessandro Valignano (1575-1606)

Alessandro Valignano is key to understanding the entry of the Jesuits Michele Ruggieri and Matteo Ricci into the Ming Empire. His insight and experience of the mission in
} 
Japan made him aware of the importance of mastering the Chinese language as a sine qua non for gaining access to the Middle Kingdom. The Visitor of the mission was the prime authority of the China Mission and the true founder of this enterprise. Nevertheless, relations between Valignano and China were either considered from a generic point of view or, conversely, in such detail that they had been reduced to a few specific circumstances. This article aims to locate and consider some unpublished European sources about the Father Visitor of the Jesuits, Alessandro Valignano, and his opinions and organization of the China Mission during the sixteenth and seventeenth centuries. The study concentrates on primary sources ranging from Valignano's first contact with China to his grand plan of a Roman Embassy to China (1588-1603), while also examining his relationship with Matteo Ricci.

Keywords

Valignano; China; mission; Jesuits; embassy

A Mark Mir

El primer estudioso que bosquejó las líneas de investigación precursoras acerca de Alexandro, modernamente Alessandro, ${ }^{1}$ Valignano, o quizá Valignani (Bernard 1938: 378-385) (Chieti, febrero de 1539; Macao, 20 de enero de 1606), y la entrada del cristianismo en la China del siglo xvi fue el jesuita Pasquale D'Elia (D’Elia 1941: 124-135). Como un «jefe excepcional» y «hábil estratega», según el estudioso italiano, Valignano persistió en el ambicioso proyecto ideado por san Francisco Javier de derrotar el paganismo en la sociedad china o, dicho de otro modo, instaurar la Iglesia cristiana en la tierra de Confucio. El jesuita trató de conseguir semejante objetivo a través de la asimétrica acomodación o inculturación en Japón de Compañía de Jesús, que, a su vez, estuvo estrictamente

1. En chino 范禮安. 
conectada con las acciones de los misioneros que estaban sujetas a las decisiones del poder político local (Hosne 2013: 60). ${ }^{2}$ Las pocas veces en las que se ha reflexionado sobre el complicado binomio Valignano y China solo se ha hecho referencia al gran aporte del jesuita italiano en la historia de las misiones en Asia, es decir, la adaptación a las costumbres en la inculturación asiática ${ }^{3}$ que todos los misioneros, o casi todos, decidieron adoptar en la empresa. ${ }^{4}$ Dicha estrategia supuso un esfuerzo titánico solo justificado por el hecho de la entrada «definitiva» de la doctrina de Cristo en Asia. ${ }^{5}$

El objetivo del presente estudio no es trazar otra bibliografía sobre Alessandro Valignano, ${ }^{6}$ sino intentar un acercamiento, lo más detallado posible, sobre su criterio y su organización de la misión china. Para empezar, es necesario tratar de localizar y examinar algunas fuentes europeas todavía inéditas que conciernen a las normas de la tierra de Confucio. ${ }^{7}$ El principal motivo es que, pese a que nunca visitó el interior de China y que no tenía ningún tipo de conocimiento del idioma del territorio, Valignano podría ser la clave para entender la entrada de los padres Ruggieri y Ricci en el Imperio Ming en 1583. Por este motivo, es muy significativa la

2. «El resultado paradójico fue que la labor enérgica e imaginativa de los Jesuitas en pro de finalidades religiosas contribuyó sin quererlo a la secularización del pensamiento europeo, sentando las bases del pensamiento ilustrado. Si el carácter eminentemente político de la adaptación jesuita a las culturas orientales ayuda a explicar su limitado éxito local, la existencia de un impulso racionalizador con fuertes raíces medievales dentro de la Cristiandad latina permite entender que la posición jesuita tuviera resultados contradictorios: con su aplicación creativa de principios teológicos tomistas y de los recursos de la erudición y de la retórica humanistas, los Jesuitas fueron partícipes de una corriente racionalizadora que les precedía, y que les abocaba a erosionar el elemento agustino dentro del sistema intelectual de la Cristiandad latina» (Rubiés 2005: 280).

3. «La evangelización sistemática de China comienza con el jesuita P. Mateo Ricci. Entró en China en 1583 y hasta su muerte, en 1610, siguió un método de adaptación misionera que produjo frutos admirables. El método de inculturación procuraba adaptar el cristianismo a la cultura y mentalidad del pueblo evangelizado, y adoptar las tradiciones que eran asimilables al cristianismo. Ricci obtuvo gran éxito utilizando tres métodos misionales: $1^{\circ} \mathrm{La}$ aceptación de las tradiciones y de la cultura china (en concreto, aceptación de ritos o ceremonias en honor de Confucio y los antepasados, y el uso de las palabras «Tien» y «Chang-ti» para nombrar a Dios); 2 La explicación de la religión cristiana y de la filosofía occidental en lengua china (escribe obras clásicas en chino) y $3^{\circ} \mathrm{El}$ acceso a la Corte imperial, ofreciendo servicio científicos, como recurso para conseguir la predicación del Evangelio en el gran Imperio. Le siguieron otros jesuitas que prolongaron sus métodos de adaptación y de apostolado científico» (Revuelta González 2006: 146).

4. "Non era certo lui che avrebbe voluto "europeizzare" i popoli dell'Estremo Oriente. Egli voleva invece, e con forza, che in tutto quello che è compatibile col domma e con la morale envagelica, i missionari si facessero indiani in India, cinesi in Cina e giapponesi in Giappone. Così pel cibo, per le vesti, per i costumi social, insomma per tutto quello che non è peccato» (D'Elia 1941: 132). 5. D’Elia (1941: 124).

6. Uno de los perfiles biográficos más interesantes sobre Valignano lo realizó el estudioso español Lisón Tolosana (2005: 67-82).

7. No son pocos los investigadores que en las notas biográficas sobre el padre Visitador han ubicado geográficamente Chieti (Abruzos) — ciudad en la que Valignano nació el 20 de febrero de 1539- en el sur de Italia, en la provincia de Nápoles, sin referencia ninguna al Reino de Nápoles bajo la dominación española. 
relevancia que tienen sus escritos redactados durante sus distintas estancias en Macao y que hoy quedan todavía por publicar. Curiosamente, fue el mismo Valignano quien afirmaba conocer «alguna cosa de la China y así lo entienden todos los que de ella saben que el haber hasta ahora llegado a esto es cosa que parece sueño y que se puede apenas creer». ${ }^{8}$ Asimismo, el jesuita en su Historia del principio y progresso de la Compañia de Jesús en las Indias Orientales (1542-1564) afirmaba lo siguiente:

El reyno de la China es tan diferente de todos los demás reynos y naciones que hay en todo este Oriente, assí en la qualidad de la gente y sus costumbres, como en la qualidad y fertilidad de la tierra, que no tiene quasi nenguna semejança con los otros, mas a todos excede; y es la cosa más principal y más rica que hay en todo el Oriente; y paréscese mucho en algunas cosas con la riqueza y hartura de nuestra Europa y en muchas le excede. ${ }^{?}$

La mayoría de la información general acerca de China le fue proporcionada por los jesuitas que habían conseguido tener acceso al interior del territorio, a saber, Ruggieri y Ricci. En tres capítulos de su Historia (26-28), Valignano describió las cualidades, las costumbres, la religión y el estado político chino de forma muy detallada; en ellos, destaca cierta fascinación del Visitador por el «ingenio y prudencia natural» de la población autóctona.

La Historia del Visitador fue publicada por Josef Wicki en 1944 y — como evidenció el profesor Manel Ollé- fue originariamente escrita en castellano antes de ser traducida al portugués y, sucesivamente, publicada a otros idiomas. ${ }^{10}$ Es muy difícil conocer la relación entre este escrito y otras cartas enviadas por los jesuitas en esta época. En el pasado, los estudiosos Wicki y Donald T. Lach (Lach 1965: 802) señalaron conexiones textuales entre los tres capítulos que Valignano incorporó en la Historia con una misiva enviada por Matteo Ricci en 1584 a Juan Bautista Román. Sin embargo, pese a las similitudes de las descripciones narradas, la abundancia de información proporcionada por Michele Ruggieri y Francisco Pasio, junto con otros jesuitas de la época que recogían datos de las traducciones de libros chinos, pudieron proporcionar la información al Visitador para la composición de sus primeras descripciones de China (Ollé 2008: 48 y 52-53). Esta

8. Goa, 7 de diciembre de 1585. Archivo Histórico de la Compañía de Jesús (en adelante ARSI), Jap. Sin., 10 I, f. 106.

9. Se trascribe la versión que se encuentra en la Historia del principio y progresso de la Compañia de Jesús en las Indias Orientales (1944: 214-215).

10. Estos tres capítulos hoy se encuentran manuscritos en la Real Academia de la Historia de Madrid, en la sección "Cortes» 562, ff.519-542, en el documento titulado Relación del grande Reyno de la China, y de sus calidades, embiada por el Pe Alexandro Valiñano, Visitador de Japón y de la India, de la Compañia de Jesús, en el año de 1584. Al parecer, fueron redactados en Macao en el año 1584 y también utilizados como fuentes en el libro impreso por Guzmán (1601). Recientemente, el profesor Manel Ollé Rodríguez realizó la transcripción: <https://www.upf.edu/asia/projectes/ che/s16/valignan.htm>. 
conexión con otros autores pudo ocurrir con otro texto de Valignano, el De missione Legatorum Iaponensium ad Romanam Curiam (Macao, 1590) con los informes del padre Alonso Sánchez escritos en 1585 y 1588 (Ollé 2008: 53). No obstante, lo más importante es la conciencia de Valignano por llevar a cabo una constante actualización del conocimiento acerca de China que ya en 1583 parecía tener:

[...] se han de mudar muchas cosas en los capítulos que tratan de la China, será bien que V.P. no haga en ninguna manera imprimir ni tampoco la primera parte hasta que o de aquí o de Japón yo la tornar a enviar mejor enmendada y revista. ${ }^{11}$

Con todo ello, es obvio que la labor del Visitador fue decisiva para el éxito de Matteo Ricci (Macerata, 6 de octubre de 1552; Pekín, 11 de mayo de 1610). Valignano le conoció en el Colegio de Macerata en 1573, época en la que era rector de la institución jesuita (Malatesta 1991: 51-66). Como han señalado muchos estudiosos, el Visitador apoyó y, al mismo tiempo, guió la misión de la cristianización de China de diversas maneras. Por un lado, eligió a los padres para llevar a cabo el catecumenado, les indicó un camino parecido al seguido en Japón y les dio las directrices adecuadas para realizarlo. Por otro, ayudó económicamente en las instituciones que la Compañía iba fundando poco a poco en el interior del país asiático (D’Elia 1941: 128-129).

Para entender mejor las estrechas conexiones entre Valignano y la misión de cristianización de China, es necesario empezar por su entendimiento y primeras impresiones de dicha tierra, por supuesto indirectas, «per informatione che mi davano et discorso della speculatione como é del bianco al negro», ${ }^{12}$ acerca de esta empresa. Los portugueses llegaron a "Amacao» en el año 1556. El nombre compuesto de la ciudad, que, posteriormente, pasó a llamarse Macao, indicaba una divinidad local «Ama» $\mathrm{y}$ «gau» que significaba «puerto» (Fontana 2005: 32). Según Luís Frois, los europeos llegaron por primera vez en 1555 a una isla al oeste de Macao llamada Lampacau. En ella vivían alrededor de 400 portugueses y cinco padres que decían misa en una iglesia edificada rápidamente. Macao, que en esa época contaba con una «rua cercada de grades de madeira, dando acceso a 4 quarteiróes» (Basto da Silva 1992: 40 y 50-54) y nada más, llegó a ser cuartel general de los portugueses. Los mercaderes lusos, considerados por los chinos «bárbaros y gente indómita y brava» (ARSI, Jap. Sin., 11 I, f. 4), muy pronto tuvieron la exclusividad en el comercio entre China y Japón, pagando los impuestos a la capital, Pekín. ${ }^{13}$ En 1601, Valignano entendía la situación en China de la siguiente manera:

11. Ib., p. 54. ARSI, Jap. Sin. 9 II, f. 213v. (Valignano 1944: 101*, n. 1).

12. Kuchinotsu, 5 de diciembre de 1579 ARSI, Jap. Sin., 8 I, f. 242.

13. Según D’Elia (1941) tras la llegada de Valignano, Macao contaba con alrededor de 10.000 habitantes. 
Cuanto a lo que toca a la China, primeramente es la ciudad de Amacao que es puerto de la China en que los portugueses tienen un pueblo grande para la contratación que tienen de la India con los chinos. Y de este puerto para Japón se hizo habrá 6 o 7 años un colegio de nuestra Compañía en que de ordinario están hasta cincuenta personas. (ARSI, Jap. Sin., 14 I f. 81)

El 6 de septiembre de 1578, el jesuita italiano llegó por primera vez a Macao tras haber estado algunos años viviendo en la India. En la «Cidade de Madre de Deus» — nombre que los portugueses dieron a Macao- permaneció otros nueve meses antes de partir hacia Japón (Üçerler 2013: 45). Aunque el estudioso D’Elia afirmó que Valignano ignoraba la historia de los monjes nestorianos en China $^{14}$ antes de la llegada de los misioneros, el jesuita de Chieti tenía cierto conocimiento previo tanto de Macao como de la llegada de los portugueses y los pasos iniciales de los misioneros en estas tierras. En uno de los primeros documentos que hoy se encuentran en el archivo de la Compañía de Jesús, se observa cómo el Visitador discurrió sobre la ciudad de Macao y la inaccesibilidad del territorio en el interior de China debido a la decisión del rey de prohibir el acceso. El documento se redactó en Goa el 25 de diciembre de 1575 y quizá fueron estos sus primeros comentarios acerca del país:

Il porto della Cina è una popolazione di portoghesi dove vanno essi et gli cini a contrattare perché il re della Cina non vuole che vadino a contrattare dentro delle città delle suo regno. Tiene ivi la Compagnia e una cassetta con la sua Chiesa et [...] ivi ordinariamente tre o 4 di di noi aggiuntando gli portuguesi et alcuni [...] dell'altra. [...] tiene ivi altra entrata ma vivono di elemosina che gli portughesi [le danno].

Goa, 25 de diciembre de 1575. (ARSI, Jap. Sin. 7 I, f. 306)

El tráfico de la mercadería en Macao estaba controlado por tres procuradores (uno de ellos solía ser un jesuita) que garantizaban una división de los bienes adquiridos en Cantón siguiendo algunas de las reglas establecidas, de manera que todos los mercaderes residentes en la ciudad pudieran obtener ganancia. Por supuesto, los jesuitas también participaban de la venta de la seda con un acuerdo, al parecer, favorable que, posteriormente, fue mejorado por Valignano, ya que garantizaba cada ańo un porcentaje fijo del producto. Esta iniciativa fue criticada más tarde por algunos miembros de la Orden, pese a la aceptación por el papa Gregorio XIII y, tiempo después, por el general Acquaviva (Fontana 2005: 33). ${ }^{15}$

Asimismo, Valignano siguió muy de cerca la formación del Colegio de Macao, institución que se puso en funcionamiento en diciembre de 1565, época

14. Cf. Malek y Hofrichter (2006).

15. También en Spence (1984: 175-176). 
en la que Manuel Teixera, Francisco Perez y André Pinto llegaron a la ciudad (Witek-Reis 1999: 30). Con mucho entusiasmo escribía el 7 de febrero de 1579 acerca de las comodidades habilitadas en el nuevo edificio de la Compañía y del avance de la construcción del colegio:

A casa de novo fizemos já pela graça de nosso Senhor está acabada e de toda coberta de telhas e ficou mui fermosa e bem assombrada com descobrimentos maiores quem Cochim y de Goa e com dois corredores mui fermosos de [...] de largo com refectório e são [...] e todas as mais oficinas muitos cómodas e capazes e fica esta casa tal que não se de nem a Chim nem a Baçaim... (ARSI, Jap. Sin., 8 I, f. 219v)

Es emblemática, y muy conocida por los estudiosos, la exclamación que Valignano pronunció probablemente desde la ventana del Colegio de Macao mirando hacia el impenetrable interior de China: «O rocca! O rocca! Quando finalmente ti aprirai al Vangelo?» (Semedo 1667: 253). Sea o no verdad esta referencia del padre portugués Alvaro Semedo, el Visitador, recién llegado a Macao, puso muy pronto su primer proyecto en marcha: aprender lo más rápido posible el idioma para destruir el «bajo concepto que los chinos tienen de toda gente extranjera» (ARSI, Jap. Sin., 14 I, f. 140). Muy pronto entendió que su estudio -otra de sus eficaces maniobras - era condición sine qua non para conseguir el acceso a China. Por este motivo, el jesuita italiano organizó desde el primer instante el aislamiento de algunos misioneros de las distracciones diarias para que se dedicaran solo a la práctica del idioma. ${ }^{16}$ Además, decidió cuidarlos para que no les faltase nada y, sobre todo, evitarles todo aquello que desviara su atención con el fin de que pudieran centrarse exclusivamente en el estudio y la práctica de la lengua y cultura china. ${ }^{17}$ Con todo ello lo que pretendía era aprender rápidamente el idioma para —utilizando sus palabras - "prevenir con el tiempo" que el lenguaje no fuera un obstáculo más en la cristianización de aquellas tierras. Así, el primer jesuita iniciado al idioma chino por el padre Visitador fue el italiano Michele Ruggieri (Spinazzola, 1543 - Salerno, 11 de mayo de 1607), substituto del calabrés Bernardino de Ferraris, primer elegido tras la petición escrita al Provincial de la India, Rodrigo Vicente. Antes de embarcarse para Goa con cinco jóvenes japoneses recién cristianizados que, posteriormente, llevó a Roma, Valignano decidió enviar a Ruggieri junto con el padre Francesco Pasio, pese a que no conociera el idioma chino. Los dos jesuitas llegaron a Zhaoqing entre el 27 de diciembre de 1582 y marzo de 1583, invitados por el dutang, el comisionado imperial de la provincia de Guangdong, Chen Rui (Ollé 2000: 114).

16. «Mas el modo que se me ofrece y que a Japón fui encaminando a este que algunos de los más padres aprendiesen muy bien las letras y la lengua de la China, de modo que no solo se pudiesen libremente hablar lo que quisiesen sin de perder intérpretes, mas que también supiesen leer y escribir sus letras para que fuesen de los mandarines temidos por hombres letrados» (ARSI, Jap. Sin. 11 I, f. 3v).

17. Como confirmó D’Elia, ya lo escribía en su Sumario (Ricci 1942: 157). 
Por otro lado, el 15 de abril de 1582, Matteo Ricci recibió la orden de acudir a Macao. El día 26 de ese mismo mes se puso rumbo hacia esta ciudad a la que llegaría unos meses después, el 7 de agosto (Malatesta 1991: 52). ${ }^{18}$ Cabe señalar que, en un primer momento, el Visitador quiso llamar a otros cuatro o cinco misioneros e incorporarlos a la expedición. Sin embargo, tuvo que contentarse solo con ayudar a los dos italianos pioneros de la empresa china. Asimismo, Valignano tuvo que correr con los gastos de un «devoto» y reunir a los maestros de chino en la misma residencia de los nuevos estudiantes jesuitas. ${ }^{19}$

Desde el principio, el aprendizaje de la nueva lengua pareció a los religiosos una meta inalcanzable, una empresa desesperada y, sobre todo para Ruggieri, al que le daba la impresión de que era una pérdida de tiempo. En este contexto, su probable incompetencia lingüística tuvo repercusiones a lo largo de su estancia en la tierra de Confucio, que abandonó después de unos años con el fin de poner en marcha la embajada para el emperador de China (D'Elia 1941: 126). Pese a las críticas lingüísticas que recibió por parte del Visitador, según explicaba Pedro Gómez en una misiva el 25 de octubre de 1581, Ruggieri conocía alrededor de 12.000 caracteres de los 80.000 que tenía el idioma chino en aquella época (Moran 1993: 178). ${ }^{20}$

La constante atención que Valignano prestó a la misión china fue directamente proporcional a su preocupación y aprensión por la conversión, por el apoyo que de manera constante solicitaba a las instituciones, tanto a las jesuitas como a las temporales, y por la especial sensibilidad que creía que se debía tener de las costumbres asiáticas. ${ }^{21}$ El Visitador en cada misiva fue dejando un apar-

18. En chino: 利瑪竇, Lì Mădòu.

19. "Quanto a quel che tocca a questa casa della Cina sta bene accomodata perché si fece una casa molto capace e comoda e si rinnovò la Chiesa et [anche se] non abbia nessuna entrata si possino comodamente sostentare dieci o dodici della Compagnia [...] e per il molto che si può fare di servitio a nostro Signore nella conversione della Cina prevenendoci con il tempo come è necessario per imparare una lingua tanto difficile e nova. Ha già tre anni che feci venire il P. Michele Rugeri che in questo tempo ten fatto notabile profitto in quello che impara e quest'anno fece venire il P. Matteo Riccio perché fosse in questa impresa compagno et ambedue vanno con grande fervore imparando et io desidero che altri quattro o cinque fratelli potessero attendere a questo ma non si può far tutto quello che si vole in un tempo ne questa casa può per adesso con tanto carico e questi doi tengono necessità di molte cose per potere andare avanti e perciò gli ho dato le comodità necessarie di abitazione di maestri e della spesa facendoli vivere di un certo modo separati e neanche nella stessa casa perché attendino ai suoi studi e non siano ne li ministeri ordinari di casa occupati con gli altri padri, perché si hanno di far profitto tutto questo necessario e per la spesa ci aiuta un nostro devoto che ha pigliato questa impresa a sua carico, ma perché alle volte può occorrere che i rettori di questa casa non considerano se non il presente...». Macao 17 de diciembre de 1582 (ARSI, Jap. Sin. 9 I, ff. 122-122v).

20. La carta se encuentra en: ARSI, Jap. Sin., 8 I, 51v.

21. "Quanto o que toca a segunda cousa da missáo da China por quanto para se levar bem diante esta missão não somente se hão de sustentar aos padres que residem dentro na China, mas também se hão de ir criando alguns outros neste colégio aplicados a esta missão para entrar na China quando se oferecesse ocasião, há de procurar grandemente que não somente os padres que estão pola terra dentro sejam bem ajudados e providos mas que também os que os tiverem neste colégio 
tado de «actualizaciones» acerca de la delicada tarea de los dos misioneros, así como de la situación del Colegio de Macao, que cada vez adquiría un carácter más independiente y acogedor para otros misioneros. Valignano explicaba detenidamente en sus informes a los superiores cómo los misioneros conseguían ser admitidos por el tutan, es decir, el virrey o gobernador de la provincia, y cómo entraron en la ciudad de Xanquin (Zhaoqing) en febrero de 1583, recibiendo el visto bueno también de otros dos gobernadores. De acuerdo con una de las descripciones del Visitador, Zhaoqing no era el mejor lugar de la provincia de Cantón, ni siquiera el principal. Por otra parte, destaca que era una ciudad «muy larga aunque poco ancha como son ordinariamente todas las ciudades de la China» y gobernada por un solo señor. Su importancia se debía tanto a la obligación que los mandarines tenían de visitar al tutan que residía allí, motivo por el que estaba bastante poblada, como a la residencia que hicieron allí los jesuitas. ${ }^{22} \mathrm{El}$ entusiasmo y la positividad inicial de Valignano es palpable en cada carta: «Irse haciendo conocer por la China y ellos reconocer la tierra y poder ir por ella seguramente» fue sin duda el primer objetivo a seguir tras la entrada al interior del país (Goa, 6 de diciembre de 1587; ARSI, Jap. Sin., 10 II, f. 294).

La información que el Visitador enviaba sobre China a sus superiores no la experimentaba él in situ, visitando cada lugar como hicieron otros, mas fue sin duda una de las más directas y cercanas a la referida por los padres que vivían en el interior. Prueba de ello es que contestaba todas las noticias que recibía con una misiva. Así, antes de su llegada a Macao, durante su estancia en Goa, Valignano recibió información del jesuita Francisco Cabral, quien en su viaje a Japón pasó por el «puerto de los portugueses».

El jesuita italiano era consciente de que la construcción de la casa y la capilla — según él, «muy frecuentada por los mandarines»— hubiera podido mejorar la conversión de los chinos. Cabe destacar que, por otra parte, siempre animó a sus compañeros a ser cautelosos, prudentes y, quizá, más racionales. Incluso creía conveniente no tener «trato con los portugueses de Macao y mucho menos con los castellanos que a veces van de los luçones allí de los cuales ellos tienen muy grande sospecha» (Goa, 27 de diciembre de 1585; ARSI, Jap. Sin., 10 I, f. 115). El Visitador exhortaba a sus compañeros con el fin de que tuvieran cuidado con sus acciones para no «enojar» a los mandarines y evitar a toda costa una expulsión, que hubiera llevado, inevitablemente, al fracaso de la misión.

aplicados a esta missão se afeiçoem a ela e não aprendendo os costumes, língua e letras chinas quanto boamente se puder. Os que vivem pola terra dentro se ande prover dom ordenado que lhe manda». Documento sin fecha (ARSI, Jap. Sin 14 II ff. 230-b, 230bv).

22. «En esta ciudad han hecho los nuestros una casa a las buena y acomodada para una pequeña residencia porque es sobradada y tienen una sala so cuatro cubículos, dos de una parte y dos de la otra, y una veranda que está en la fontería de la sala y debajo tienen los mismos aposentos y lo que está debajo de la sala sirve ahora en lugar de iglesia». Macao, 10 de noviembre de 1588 (ARSI, Jap. Sin. 11 I, f. 1). 
Por su lado, los jesuitas «comenzaban a ser conocidos de los mandarines y hacer algunos cristianos con aplauso sin ser extrañados de ellos». A través de las cartas de Valignano, se observa que tras recibir nueva información sobre el progreso de la religión cristiana en Zhaoqing, el Visitador decidió despachar a otros padres para la misión de China ${ }^{23}$. El jesuita italiano optó por el padre Duarte de Sande, superior de la misión y prefecto de los estudios en el Colegio de Goa (D’Elia 1941: 129), y a Antonio de Almeida como posibles apoyos para Ruggieri y Ricci.

Debe señalarse, por otra parte, las muchas dudas que atemorizaban a los jesuitas acerca de la posibilidad de no conseguir el acceso al interior de China. Quizás, una de las mayores preocupaciones del Visitador fuera la «intrusión» de los franciscanos en Asia, una inquietud que le persiguió en particular en la misión de Japón y por la que llegó a escribir su famosa Apología (Valignano 1998). Así, el 7 de diciembre de 1585, desde la residencia de Goa, Alessandro Valignano confirmaba: «solo una cosa me da alguna mala espina en el corazón [...] y es que este año volvió aquí un fraile descalzo llamado fray Martinho Ignacio pariente de nuestro santo padre Ignacio de Loyola». Por aquel entonces, una carta del rey permitió a los descalzos obtener el permiso necesario para intentar la empresa en China. ${ }^{24}$ En todo caso, este propósito de los frailes — según opi-

23. «De la China también supimos que fue nuestro Señor servido, que el medio que se tomó ahora seis ańos de determinar al padre Rogerio con otro compañero, que de propósito estudiase la lengua china, no salió de balde porque finalmente alcanzaron de ser admitidos en la China, en una ciudad principal llamada Xanquin, de la provincia de Cantón, adonde reside el virrey o gobernador de la provincia que llaman tutan y con su licencia que fue ya confirmada por tres tutan que en este tiempo se mudaron; después que yo de allá partí, hicieron una muy cómoda casa con su capilla, la cual es muy frecuentada los mandarines e hicieron ya cristianos dos personas honradas e principales y otras se catequizaban y pedían el santo bautismo y aunque ellos conforme al orden que yo les dejé procedían con mucho tiento en hacer cristianos para no causar alguna revuelta con la cual fuesen excluidos de la China hasta ser en ella conocidos y confirmados. Todavía, con estos dos que se hicieron, no tomaron ningún enojo los mandarines, antes algunos de ellos dieron el parabién a los convertidos y a los mismos padres, diciendo que holgaban que un hombre tan conocido como era uno de ellos que estaba para ser luego hecho mandarín, se convirtiese y que otros muchos también se conversarían y este después de convertido se fue a la corte de Pekín para tomar la dignidad de mandarín que esperaba y porque también estas nuevas fueron a V.P. por las mismas vías no me alargo en las escribir; mas solo digo que son tan buenas y felices que aún en un cierto modo no las puedo creer aunque con ciertas y las tengo por cartas de los mismos padres y del padre Francisco Cabral que los fue visitar de Amacao y porque así del Xanquin como de Japón pedían padres. Hacemos lo que podemos para enviar algunos, y aunque desacomodados diversas casas y colegios de esta provincia, no hubo remedio y mandaremos seis padres de los cuales dos van para Xauquin y cuatro a Japón. Son los padres Duarte de Sande, que fue rector de Baçain, profeso de cuatro votos que ahora leía teología y con perfecto de los estudios en el colegio de Goa y por ser hombre de muchas partes y de prudencia y virtud lo escogimos para superior de esta misión de la China; los otros son el padre Pedro Crasso y el que estaba por ministro en Baçain y el padre Francesco Mongavero, que estaba en la Costa de Travancor...». Goa, 1 de abril de 1585 (ARSI, Jap. Sin. 10 I, f. 25).

24. "Vino este padre por custodio de los frailes descalzos que están en Macao y con licencia de su Majestad para intentar esta impresa de la China, aunque en la misma carta que trajo de 
naban los jesuitas «insensato y peligrosos»— pareció fracasar repentinamente. La responsabilidad de este resultado adverso fue atribuida al fray Martinho por actuar «sin razón y sin prudencia»; ${ }^{25}$ mas el principal temor de Valignano era que el religioso portugués y otros seis compañeros pudiesen echar a perder aquel «sueño que se puede apenas creer», a saber, la aceptación en tierra china.

Tras la segunda estancia del Visitador en Macao, que según relató Ricci fue desde el 9 de marzo hasta el 31 de diciembre de 1585, Valignano comenzó a ocuparse con más esmero de la misión de China (Malatesta 1991: 52). Para ello, el italiano tomó la notoria decisión de introducir a los jesuitas como "hombres letrados que habían venido de lejos a la fama que había de la sabiduría y letras de la China». Bajo esta premisa, el Visitador utilizó esta estratagema que, desde su punto de vista, era esencial para mantener el «pequeño postigo a su Santo Evangelio ${ }^{26}$ en aquellas tierras. En tales circunstancias, el primer paso a seguir fue el de mandar a traducir al chino escritos necesarios como el Decálogo, el Padrenuestro, el Avemaría y, probablemente, el Credo (D’Elia 1934: 194). En este sentido, se comprende que, unos ańos antes, Michele Ruggieri sintió la necesidad de escribir un libro de apologética para relacionarse con los "paganos» (D’Elia 1934: 196) tras su llegada a Macao en julio de 1579. La obra fue compuesta por el italiano en 1585 y se tituló Catechismus R.P. Michaelis Rogery;

S. Majestad el virrey sobre esto, venía una cláusula en que decía que le ayudase para que entrase en la China; mas por cuanto el principal cuidado de la conversión de los infieles de aquellas partes del sur, estaba encomendada a los padres de la Compañía que iban prosiguiendo la conversión con mucho provecho, era su voluntad que de tal manera se favoreciese la entrada de los frailes, que de ninguna manera se causase estorbo a los dichos padres de la Compañía, los cuales quería que fuesen en esto ayudados, que por esto se guardase la orden que el año pasado le tenía dado. Esta era la cláusula de dicha carta y la orden que el año pasado dio acerca de los mismos frailes, que de ninguna manera fuese a Japón ni a las partes de la China a do los padres de la Compañía estaban. Pésole mucho [...] la ida de este fraile para aquellas partes, segundo el mismo me dijo [...] y que se quisiese entrar en la China fuesen a otra provincia, y les aconsejó que sería mejor esperar en Macao. La respuesta de S. Majestad al cual me dijo [...] lo que sentía que era que ya que los padres tenían dado ahí tan bien principio no convenía que fuesen por ahora ahí otros frailes, aunque para la mucha [suspición] que tienen los chinos no se puede esperar de esto sino daño...». Goa 7 de diciembre de 1585 (ARSI, Jap. Sin. 10 I, f. 106).

25. "[...] y a los frailes fueran allá, aunque su Majestad ordenó el contrario, como también contra orden de S. Majestad y del virrey, intentaron también de entrar en la China y fueron presos, y echados de los mandarines, mandándoles que nunca más volvieron allí y azotándolos cruelmente en su presencia el intérprete que traían y poniendo en muy grande peligro la misión de los nuestros y todos los portugueses que estaban en Cantón y sobre esto escribió la ciudad de Amacao al virrey muy grave y pesadamente contra los frailes; y el virrey está muy sentido de ellos por hacer contra el orden que él les dio y si yo no me prestara en escribir a los nuestros que estaban dentro de la China que ni por mal ni por bien trataré con los frailes si fuesen allá, por no hacer sospechosos a los mandarinos, fácilmente se perdiera la dicha misión y el bueno del fraile Martino Ignacio que es el que revuelve todo esto». Goa, 6 de diciembre de 1587 (ARSI, Jap. Sin, 10 II, f. 294. También en ARSI, Jap. Sin, 11 I, f. 1v).

26. Lo vuelve a repetir en una carta desde Goa, 19 de enero de 1586 (ARSI, Jap. Sin. 10 I, ff. 147-147v). 
más tarde, se tradujo al chino bajo el título T’ien-chu shih-lu (Chan 2002: 96). Este último escrito es un tratado «en que se declaraba la sustancia de adorar y finalmente de la creación y modo de nuestra redención y de todo lo demás que servía de creer y hacer para alcanzar otra vida» (Goa, 27 de diciembre de 1585; ARSI, Jap. Sin., 10 I, ff. 114v-115).

Los regalos y la vestimenta fueron el elemento insustituible para la adaptación promulgada por Valignano y sirvieron para que «fuesen conocidos por letrados y tratados como naturales de la China»:

[...] y con esto juntamente llevaron un reloj, una esfera y un mapamundi que también hicieron con letras de la China y vistiéndose al modo de los chinos con unas opas y mangas largas y bonetes de cuatro cantos de la manera que usan algunos de sus letrados. Presentaron estas cosas a los mandarines con los cuales comenzaron a tener entrada con que algunos de ellos y alcanzaron nombre de grandes letrados y por medio de ellos tuvieron entrada con el tutan que entre ellos es el supremo mandarín y virrey de la provincia de Cantón y de otra puerta y diciéndole la profesión que hacían y el intento que tenían de vivir y morir entre los chinos. ${ }^{27}$

Siendo las cosas así, es evidente que el segundo paso de su tan conocida y controvertida acomodatio (Rubiés 2012: 33-61) fuera adoptar un traje más acorde con la costumbre china, una problemática a la que se enfrentó también en Japón (Hosne 2013: 61). Pero en China, la orden imperial no permitía a las diferentes clases sociales "mudar o vestir de otra manera». De modo que los jesuitas, después de fracasar en el primer intento de utilizar el hábito de los religiosos chinos, considerado como "harto bajo y vil» (ARSI, Jap. Sin., 11 I, f. 7), decidieron utilizar el traje tradicional empleado por los mandarines. Esta decisión suscitó no pocas críticas a las que el Visitador se enfrentó en varias ocasiones. ${ }^{28}$ El motivo de tomar esta decisión lo expresó unos años más tarde de la adaptación, el 21 de octubre de 1600, en Nagasaki: los bonzos chinos fueron «tenidos de los mandarines en bajísima cuenta». ${ }^{29}$ Así que los padres acordaron el siguiente cambio:

[...] determinamos que los nuestros no rapasen las barbas ni cortasen los cabellos ni truxessen mas trajo ninguno de bonzos ni tuviesen tal nombre y que en su lugar tomasen el vestido y nombre de letrados que profesan enseñar las cosas de la otra

27. Ib., f. $114 \mathrm{v}$.

28. «Y cuanto a lo que dicen que dejamos nuestros cristianos y tomamos otros nombres extrańos y gentilicios, es tan grande falsedad que ni sé cómo ni dónde la pudieron imaginar, si no fue por las mismas razones por que nos llaman herejes y temerarios como V.P. verá en las respuestas que dieron». Macao, 30 de octubre de 1588 (ARSI, Jap. Sin., 10 II, f. 227v).

29. Más tarde afirmó: «Ahora después que tomaron hábito y nombre de letrados, son tratados con tanto respeto de todos los mandarines como si fueran sus iguales. Especialmente el padre Matheus Ricio es muy visitado y honrado en Pekín de todos los mandarines honrados». Macao, 12 de noviembre de 1603 (ARSI, Jap. Sin., 14 I, f. 140). 
vida, dejando crecer las barbas y trayendo el cabello crecido hasta las orejas de la manera que hacen los nuestros en Alemania. (ARSI, Jap. Sin., 14 I, f. 38)

Valignano describió con todo lujo de detalles el traje de los letrados como una vestimenta:

[...] cumplida a la manera de los que en la India llaman catabiras que es abierta toda adelante y atando parte bajo de un lado las puntas de ella con una [cinta] la tornan a cubrir con las otras puntas atado con el otro lado y tienen unas mangas largas. (ARSI, Jap. Sin., 11 I, f. 7)

Su descripción del bonete típico de los chinos fue aún más exhaustiva y la comparó con la usanza europea: «era de cuatro cantos de la misma manera que se usa en España que son más altos de los que usamos en Italia y aún estos tienen mayor altura que los que se usan en España» (ARSI, Jap. Sin., 11 I, f. 7). ${ }^{30}$

Según parece, los religiosos autóctonos solo se tuvieron en cuenta a modo de "pasatiempo y recreación" de los mandarines, quienes hacían banquetes en sus casas y los azotaban por cualquier motivo. En este contexto, los misioneros se vieron obligados a poner a disposición de los mandarines su residencia en Zhaoqing por estar «sujeta a este enfadamiento», y a preparar las ceremonias necesarias para agasajar a los mandarines y ser muy complacientes con ellos sobre las «cosas curiosas» que captaban su atención. ${ }^{31}$ Como subrayó Gernet, además de la adaptación al medio de los letrados, los jesuitas intentaron «impresionarlos con las ciencias de Europa» (Gernet 1989: 34). Según el Visitador, debido a la actitud de los mandarines, los primeros años en Zhaoqing no fueron nada fáciles para los jesuitas que «padecían muchas deserquietaciones y distracciones» (ARSI, Jap. Sin., 11 I, f. 1v). Los chinos consideraron a los misioneros hombres ricos, tanto por la cercanía de los jesuitas con los mercaderes portugueses como, según Valignano, por la «miseria y escasez en el modo de vivir». ${ }^{32}$ Del mismo modo, los padres de la Compañía y el Visitador advirtieron que los mandarines no respetaban ni tenían en "cuenta de sus sacerdotes y padres», como también

30. «Mas porque todo el paño de la China es como entre nos paño de lino, aunque es aquí de algodón, siendo de cualquier color, también es muy bajo y para los nuestros será aun [...] más desconveniente y si se han de meter alguna manera de autoridad religiosa, parece necesario ahora vestir alguna [pieza] de seda de la China que valen aquí muy baratas y son muy convenientes a todos de color prieto o de color rojo muy obscuro que nosotros llamamos a Roma pavonazo oscuro, que va a ser casi prieto y esto así lo dicen los padres que sabían las costumbre de la China» (ARSI, Jap. Sin., 11 I, f. 7).

31. «[...] los mandarines saben que los padres tienen alguna cosa curiosa, o de estima, luego la piden y desean y porque dependemos tanto de su favor, es necesario dárselas» (ARSI, Jap. Sin., $11 \mathrm{I}, \mathrm{f} .1 \mathrm{v})$.

32. Ib. f. 2 v. 
ocurría en Japón. ${ }^{33}$ El motivo principal era la gran atracción de los chinos por la filosofía moral y sus "libros antiguos que tratan buenas cosas para la vida política», es decir, Los cuatro libros de Confucio, ${ }^{34}$ que les hacía reacios a cualquier otro tipo de fe.

En un documento sin fecha redactado en Macao y titulado Os avisos seguintes sáo somente para o Reitor do Colégio, Valignano reflexionó de manera clara y precisa acerca de la conveniencia de adoptar el «nome de letrados» para ser más tenido en cuenta por los mandarines. ${ }^{35}$ Otra forma de intensificar y justificar el asentamiento al hábito chino fueron sus narraciones intercaladas en algunas de las misivas relacionadas con China, en las que incluyó «célebres» episodios como demostración de los avances de la cristianización en aquellas tierras. Entre otras, Valignano mencionó una de las primeras historias de conversión al cristianismo chino, la anécdota de Paulo ${ }^{36}$ (Xu Guangqi, 1562-1633), el gran secretario del

33. «[...] en Japón fue otra cosa, porque los bonzos en todas las sectas tenían entre sus naturales suma de autoridades y así bastaba en Japón saberse que los nuestros eran padres y bonzos para ser con ancha cortesía y respeto tratado y les podían libremente hablar» (ARSI, Jap. Sin., 11 I, f. 2v). 34. «De tal manera que entre ellos el ser sacerdote y padre es uno de los más abyectos y viles oficios que hay entre ellos» (ARSI, Jap. Sin 11 I, f. 1-1v). Meynard (2015); Confucio (1963).

35. «Porque os bonzos da China são tão abatidos e tidos em na conta dos mandarins que os nossos com este nome de bonzos ficam perdendo muito crédito e reputação parece que será melhor ter por algum tempo nome de letrados que bonzo pelo qual parecem bem e conveniente não ir rapados como náo os bonzos puderam os que estiverem pola terra dentro fazer crescer as barbas e também o cabelo até ao velha de maneira que costumavam os portugueses no tempo antigo, e agora não os nossos padres em Germania» (ARSI, Jap. Sin 14 II, f. 230).

36. «E hízose en este tiempo tan capaz que entendió muy bien todo lo que estaba escrito por diálogo aquel catecismo. Y como era buen letrado en las letras de los chinos [arridó] mucho a los padres reducir a perfección el catecismo, el cual, después de bien examinado, lo hicieron luego imprimir en lengua china. Él se bautizó y se fue a la corte a tomar el grado de mandarín con intención de pasar por su tierra a catequizar luego su mujer e hijos y bautizarlos y dar en la corte nuevas y razón de tan singular doctrina y llevó para dar los mandarines algunos de los dichos catecismos. Quísose llamar Paulo, y será nuestro Señor servido de comunicar a este hombre alguna cosa del espíritu de São Pablo para hacer en la China muchos servicios y lo que es más para estimar que sabiendo los mandarines que estaban en aquella ciudad que este se había bautizado, no solo no lo tomaron mal ni estorbaron que no se hiciese, mas antes lo loaron, y muchos de ellos fueron a los padres a darles el parabién por haber alcanzado por su discípulo un hombre tan letrado. [...] E hízose en este tiempo tan capaz que entendió muy bien todo lo que estaba escrito por diálogo aquel catecismo. Y como era buen letrado en las letras de los chinos [arridó] mucho a los padres en reducir a perfección el catecismo, el cual después de bien examinado lo hicieron luego imprimir en lengua china. Él se bautizó y se fue a la corte a tomar el grado de mandarín con intención de pasar por su tierra a catequizar luego su mujer e hijos y bautizarlos y dar en la corte nuevas y razón de tan singular doctrina y llevó para dara los mandarines algunos de los dichos catecismos. Quísose llamar Paulo, y será nuestro Señor servido de comunicar a este hombre alguna cosa del espíritu de São Pablo para le hacer en la China muchos servicios y lo que es más para se estimar que sabiendo los mandarines que estaban en aquella ciudad que este se había bautizado, no solo no lo tomaron mal ni estorbaron que no se hiciese, mas antes lo loaron de eso, y mucho de ellos fueron a los padres a darles el parabién por haber alcanzado por su discípulo un hombre tan letrado" (Ib., ff. 114v-115). 
Imperio que guió la gran reforma china y que fue autor de varias traducciones de libros científicos occidentales y de un importante tratado sobre la agricultura (Jami, Engelfriet y Blue 2001: 1).

El Visitador recogió varios episodios de conversión que tuvieron lugar en diferentes situaciones ${ }^{37}$ y de distinta tipología, gracias a los testimonios que sus compañeros le enviaban. Los padres asentados en China comprendieron que los mandarines — burócratas y, a la vez, estudiosos «distintos por grados conforme a los oficios y dignidades» (ARSI, Jap. Sin. 11 I, f. 1v.) — eran difíciles de iniciar a la doctrina cristiana debido a su índole de «sospechosos y percatados en su gobierno». Conforme a los escritos de Valignano, los mandarines eran a menudo «contradictores»y, por tanto, no solo desconfiaban de la fe y la labor de los jesuitas, sino que incluso llegaron a sobornar a la gente para desacreditar a los padres. ${ }^{38}$ Atendiendo a las palabras del Visitador, los altos funcionarios chinos menospreciaban a los jesuitas, los tenían con «tan bajo foro» ignorándoles, sin hablarle ni para bien ni para mal (ARSI, Jap. Sin. 11 I, f. 2v). En cambio, según los jesuitas, los mandarines tenían muchos prejuicios y, al mismo tiempo, eran «miedosos de no perder sus oficios»; por ello, huían de tener algún tipo de contacto o conversación con los forasteros (ARSI, Jap. Sin. 11 I, f. 1v). En uno de sus largos escritos, el Visitador criticó con profusión a los mandarines por su actitud, por ser "intratables e inconversables», y por hacerse «adorar como dioses». Tras varios intentos, los misioneros fueron captando la manera correcta de tratar con ellos, dirigiéndose a ellos con «toda la honra y reverencia posible». Aunque la escasa consideración de los chinos les resultara poco agradable, teniendo en cuenta el ínfimo aprecio que aquellos profesaban por otras clases sociales y por los extranjeros, los jesuitas eligieron, en un principio, claudicar con el fin de ser aceptados como religiosos. Al compararse con los monjes chinos en esta fase inicial del encuentro, los padres accedieron a conversar con los mandarines "de rodillas y mostrarles muy grandes sumisiones», ya que, según Valignano, los oficiales no creían «en ninguna cosa» (ARSI, Jap. Sin., 11 ff. 1-1v).

37. «Bautizóse también con el otro, aunque no era de tanto ser, era todavía mercader casado en aquella ciudad que ni su mujer ni su vecinos y amigos, con quien se comunicó, le fueron a la mano. Antes algunos de ellos, informados de esta nueva doctrina y fe que tomaba, les pareció bien y dijeron que también ellos querían oír esta doctrina» (ARSI, Jap. Sin 14 II, f. 115).

38. «Todavía no faltan contradictores porque nuestro cruel enemigo parece que siente mal entrar en su tierra la ley de nuestro Señor porque bien sabe que entrando esta, se ha él de salir, y por eso [preservará] los corazones de muchos y que levante muchas falsedades contra los padres y así algunas veces los acusaron falsamente los mandarines, unos diciendo que eran espías venidos para hacer algún mal a aquel reino y otros que venían para hurtar niños y venderlos a los portugueses y afirmando que así lo hacían y llevaron un niño sobornado para esto a los mandarines y fueron los padres llamados y examinados dichos mandarines y con los falsos testimonios que les levantaban se [vieron] en gran aprieto. Mas nuestro Señor que tiene cuidado de los suyos los libró y justificó delante de los mandarines. De manera que los declararon inocentes; los acusadores fueron muy bien azotados conforme a su costumbre» (Ib., f. 115). 
Según fue avanzando la misión en Asia, con un constante hermetismo chino, el padre Visitador decidió aprobar la formación de un clero local (otro interesante paralelismo con Japón; incluso empleó el término japonés dojuku para definir a los hermanos chinos (ARSI, Jap. Sin., 14 I ff. 38v) con el fin de aportar un apoyo básico y para que quedara «bien confirmada esta misión». Así, los nativos chinos podían ser admitidos como dojuku pero no como miembros de la propia Orden (Schütte 1985: 250). ${ }^{39}$ Además, Valignano y sus colaboradores creyeron necesaria la creación de un "seminario de los naturales [...] recibidos por hermanos», con el objetivo de reducir las dificultades tanto lingüísticas como de aceptación por parte de la población china. La elección de los miembros chinos tenía que efectuarse entre las familias de "padres cristianos» y —añadía - «criados entre nosotros». Las cualidades que debían reunir para ser seleccionados eran el conocimiento previo de la doctrina, que los nuevos hermanos no fuesen ajenos a cierto tipo de prácticas religiosas y que, sobre todo, los neófitos tuvieran «afición» por el cristianismo. ${ }^{40}$

A partir de 1598, la principal preocupación de Valignano fue la entrada de otras órdenes en China. ${ }^{41}$ De sus cartas se desprende que la misión de difundir la doctrina cristiana en la tierra de Confucio continuó al año siguiente, aunque con altos y bajos a causa del exceso de religiosos de diferentes órdenes. ${ }^{42}$ Además, el je-

39. Esta decisión se encuentra en el capítulo XIII del Sumario: «Y con esto había de prohibir Su Santidad que ningún japonés se pudiese ordenar si no es con divisoria del Superior universal de Japón, y juntamente que no pudiese ejercitar ningún ministerio en otro obispado sin la misma licencia, para que por caso algunos después de enseñados quisiesen ir para ordenar o vivir en la China o en otras partes la India no lo puedan hacer» (Valignano 1954: 179-180).

40. «De estos traemos ahora aquí dos [mozos] entre las [manos] que desean grandemente entregarse al servicio de nuestro Señor en nuestra Compañía. Uno es de 19 ańos y el otro de 26 que nacieron, como digo, de padres cristianos aquí y se criaron siempre en nuestras escuelas y son mancebos limpios y virtuosos que dieron siempre hasta ahora buena cuenta de sí, y si ellos quisiesen entrar en otras religiones, fácilmente serían recibidos; mas como tienen su afición a nosotros antes quieren pasar por las probas y dificultades que tirara de entrar en la Compañía que ser admitido en otras; y así están determinados de ir a estar con los padres a Xauchou y servirlos y ayudarlos en todo lo que los mandaran solamente con esta esperanza que dando buena prueba de sí en este tiempo que viniere esta licencia de V.P. pueden ser admitidos hermanos en la Compañía. Ellos son muy excelentes escribanos de los [tipos] que hay aquí y tienen buenos principios de gramática y son de muy buen ingenio y de [...] natural y tales que, sin duda, exceden a muchos de los que en la India se reciben y con estos dos otros años de experiencia que darán metido ahí mismo entre la gentilidad de la China [...]». Macao, 10 de octubre de 1589 (ARSI, Jap. Sin., 11 I, f. 183).

41. «Y si conviene que de tantas partes y religiones acudan frailes para tratar de convertir la China, como hasta ahora acudieron a Macao franciscanos, dominicos y agustinos; mas los chinos saben muy bien defender la entrada y [pliega] a Dios que un día no echen también los padres que están en Xauquin». Macao, 12 de junio de 1589 (ARSI, Jap. Sin., 11 I, ff. 81-81v).

42. "Cuanto a lo que toca esta casa de la China sea cierto V.P. que va también como todas las más casas de la India y aunque concurrieron aquí muchos religiosos de diversas órdenes, siempre quedó la Compañía en la misma estimación y crédito que tenía, aunque no puede faltar, como hay en todo lugar alguno que no guste tanto de más cosas y ni en el comer ni en el vestir a ninguna superfluidad, ni indecencia...». Macao, 22 de septiembre de 1589 (ARSI, Jap. Sin., 11 I, ff. 140140v). (Se repite también en el folio f. 144 de la misma sección). 
suita italiano y sus compañeros tuvieron que enfrentarse a dos amenazas: la primera fue la inspección del chaen, visitador general del rey, que, con frecuencia, junto con el tutan controlaban a los padres europeos y realizaban "grandes pesquisas" sobre su actividad. Según Valignano, los franciscanos fueron el objeto primordial de esta indagación tan meticulosa por parte de los gobernadores, debido a que prometieron «falsamente» que harían «venir una embajada». El Visitador explicó que el segundo riesgo que corrieron los jesuitas fueron las incesantes acusaciones de los chinos que creían que los padres eran unas copias de los portugueses «y que procuraban meter muchos padres en la China y que en este puerto de Macao se asentaban todas las bárbaras naciones». ${ }^{43}$

Pero, sobre todo, hubo un importante obstáculo que los jesuitas tuvieron que superar en la misión, en particular Ruggieri y Ricci: la estancia en Zhaoqing. Ningún natural chino quería que los padres europeos se quedasen en esta ciudad. En una larga carta desde Macao enviada a Roma el 24 de septiembre de 1589, Alessandro Valignano narró las ininterrumpidas tribulaciones que los padres sufrieron en esta población y cómo «alguns velhos do povo de Cantão» se levantaron contra los religiosos cristianos. Los motivos eran, más o menos, los mismos que se han mencionado unas líneas antes. En primer lugar, dichos desafectos se engendraron sobre la creencia de que los misioneros ayudaban a las «naçóes bárbaras» para que provocaran «alguma grande novidade na China». De nuevo, la culpa era de la embajada prometida por los franciscanos, quienes «fariam vir hum grande presente e el Rei da China que o Rei destas nações bárbaras lhe mandava».

Tras la pormenorizada investigación llevada a cabo por la insistente petición enviada por los mandarines, ${ }^{44}$ además de la visita del chaen, al tutan debía decidir sobre la suerte de los jesuitas. De la dilatada exposición del padre Visitador se desprende que el virrey chino, ya viejo, intentó complacer a los mandarines, teniendo en cuenta que él no era muy partidario de expulsar a los padres. El informe de Valignano relata un vaivén de sentencias y respuestas, de decisiones no tan tajantes y de estrategias del propio autor, ${ }^{45}$ que terminan en el favora-

\section{3. $I b$. f. $81 \mathrm{v}$.}

44. «lhe escrevera e começaram a inquirir e fazer hum processo da vida dos padres e porque não acharam cousa que lhes pudessem [empecer], tornaram a rescrever ao Tutam que estavam aí somente dois padres que vieram com licença dos Tutois passados e que inquiriram contra eles e acharam que eram homens de boa vida e que não faziam mal a ninguém, mas que se ele quisesse era bom manda-los tornar para Amacao, ficou com isto assim a causa suspensa alguns días. E entretanto vejo o Chajem a Cantão que é o visitador geral que o Rei manda cada ano de Paquim e logo lhe deram a mesma petição e ele também logo escreveu sobre isto a os mandarins de Xauquim, de modo que os mandarins se começaram grandemente a conselhar com os padres dizendo que não tinham remedio e que em todo caso si haviam de ir». Macao 24 septiembre de 1589 (ARSI, Jap. Sin. 11 I ff. 149-151v).

45. «Finalmente eles mostrando muita paciência e humildade foram a entregar claves da casa ao [Chonchisu] que é capitáo da cidade, o qual mostrava de compadecer-se deles e lhes mandava dar sessenta [taeis] em pagamento das casa que lhe tomavam pelo ter assim ordenado o Tutaó mas porque eles estavam advertidos de mim que não tomassem nada não os quiseram tomar, posto que 
ble decreto del tutan: los padres «não fizeram nenhum mal [...] se quisesse os mandaria a Caucheu (Xao Cheo)». ${ }^{46}$ Los misioneros aceptaron y muy pronto comunicaron su decisión al tutan, quien les dio «chapas e provisóes» para que se mudaran a la ciudad de Xao Cheo.

Mientras, Ricci y Almeida seguían escribiendo al padre Visitador sus crónicas desde la nueva ciudad. Le explicaron la buena acogida que tuvieron y cómo los mandarines les ordenaron vivir en una población de religiosos llamada Naoam. ${ }^{47} \mathrm{Al}$ verse «metidos entre tanto bonzos», los dos jesuitas decidieron hacer otra petición a los mandarines para poder vivir en el centro de la ciudad de Xao Cheo, por supuesto, permaneciendo «debaixo da proteiçấo dos mandarins». Finalmente, los mandarines aceptaron la demanda y les concedieron un lugar más agradable para ejercer su profesión: «Una varela grande que está fora dos muros nos [ribaldes] da cidade ao cabo de uma ponte por a qual se passa hum grande e fresco rio que é de grande comercio para diversas partes da China» (ARSI, Jap. Sin. 11 I f. 151v.).

Xao Cheo se situaba en la parte más interior de China. Ricci y Almeida encontraron cierta estabilidad en esta localidad, aunque permanecieron a la espera de la confirmación oficial y definitiva de los gobernadores imperiales. A través del texto de Valignano se vislumbra que gracias al respeto demostrado por los locales, tanto por el pueblo como por los mandarines, los jesuitas se pudieron adaptar sin ninguna dificultad..$^{48}$ Llama la atención que en estas circunstancias propicias para la cristianización, los misioneros pidieron al Visitador el apoyo de otros colaboradores chinos. ${ }^{49}$

o [Chonchisu] lhes fez sobre isto muita instancia e despedidos dele com boas palavras se vieram para Cantấo donde me escreverấo como se vinhão e estavam esperando embarcaçáo que o capitáo de Cantão lhe havia de dar» (ARSI, Jap. Sin. 11 I, ff. 149-151v).

46. «[...] que é outra cidade grande de esta mesma província de Cantão que estão mais dentro pola China e de Cantão aí se vai em doce dias por se ir contra água posto que se vem dela para Cantão em quatro ou cinco dias» (Ib., ff. 149-151v).

47. «Depois desta escrita tivemos cartas dos padres Matheus Riçio e Antonio Dalmeida que me escreveram de Xaucheu que é cidade de que arrima dissemos, de como chegaram lá a salvamento e foram mui bem recebidos dos mandarins e de gente daquela terra quando chegaram acharam já em lugar que os mandarins lhe tinham determinado em uma povoação de bonzos chamada [Naoam] que está duas outas léguas da dita cidade, onde há muitas e mui grandes varelas dos bonzos, mas porque indo elas a ver o dito lugar náo lhes contentou estar metidos entre tanto bonzos. E tornaram aos mandarins de Xaucheu, fazendo-lhe saber que não podiam estar eles com os ditos bonzos em [Naoam] que serem de diferente doutrina e diferente lei. E que desejavam estar mais na dita cidade de Xaucheu debaixo da proteição dos mandarins.» (Ib., ff. 149-151v).

48. Macao 24 septiembre de 1589 (ARSI, Jap. Sin. 11 I ff. 149-151v).

49. «y con estas nuevas enviaron aquí a pedir algunas cosas y que les fuesen los dos mancebos chinos de los cuales en otra escribieron que deseaban entregarse al servicio de Dios en la Compañía en esta misión de la China, de los cuales el uno ya está en Cantón y el otro irá entre dos días y como son muy virtuosos y buenos y que tienen mucha [...] y amor a los padres. No le será de menos ayuda y consolación que las fuesen dos hermanos y en la verdad yo también quedo con la ida de ellos muy satisfecho y consolado» (Ib., f. 188). 
En un documento escrito de 1600, Alessandro Valignano avisaba a sus superiores en Roma que Matteo Ricci y sus compañeros lograron establecer otra residencia de la Compañía en la ciudad de Nankín «la más principal y mayor de todo el reino" gracias al fortuito apoyo de un «mandarín grande». ${ }^{50} \mathrm{~A}$ partir de aquel año, los padres fueron ganando terreno y consideración en $\mathrm{China}^{51} \mathrm{y}$, en particular, con los mandarines, si bien es cierto que los jesuitas ya no les hablaban «de rodillas y [...] con palabras bajas y sin ninguna manera de cortesía».

Asimismo, con la entrada de Ricci en Pekín el 24 de enero de 1601, Valignano veía cada vez más factible la evangelización de China. Llama la atención el entusiasmo del Visitador al enterarse que los padres se encontraban en un buen estado. Ellos podían contar con una «entrada privada, particular con todos los grandes» y ser tratados "con mucho respeto y cortesía». ${ }^{52}$ Tras haber obtenido cierta deferencia por los mandarines, los jesuitas comenzaron a "comunicarles y tratarles de las cosas del cielo, de la inmortalidad de las ánimas, de la otra vida y de diversas cosas humanas». El procedimiento inicial fue fascinar a los gobernantes chinos a través del conocimiento de $\operatorname{Dios}^{53} \mathrm{y}$, mientras tanto, ofrecerles «algunas piezas curiosas [...] como relojes, imágenes, vidrios triangulares y otras cosas semejantes que por no las haber ellos nunca visto, las tienen en mucha estima». En definitiva, según Alessandro Valignano, la aceptación de los mandarines se debió a un nuevo trato «místico y familiar» que los jesuitas supieron pacientemente alcanzar con no pocos esfuerzos.

La embajada que el Visitador y sus compañeros solicitaron a la Santa Sede en el año 1588 es quizá uno de los temas que conviene analizar con más detenimiento dado que algunos documentos, hasta hoy desconocidos, se encuentran en los archivos de la Compañía de Jesús. Para tal efecto, es necesario replantear algunas líneas de investigación, posiblemente ya obsoletas, y arrojar más luz sobre este asunto. Tras la tercera visita de Valignano a Macao, que duró desde el 28 de julio de 1588 hasta el 29 de junio de 1590, el jesuita italiano intuyó

50. «Fueron el año pasado, o por mejor decir ahora dos años a Pekín llevados de un mandarín grande pareciéndole que en aquella misma corte de Pekín había de ser promovido por el rey al oficio de Colao que es el sumo de todos los magistrados que hay entre los mandarines. Mas por no salirle la traca como él imaginaba y deseaba y mandarle el rey se tornase con el mismo cargo que tenía primero en Nanquin. No pudieron los padres tener entrada con el rey y con los colaos en Pekín y así se volvieron a Nanquin adonde con el favor de este mismo mandarín hicieron la tercera residencia». Nagasaki, 4 de octubre de 1600 (ARSI, Jap. Sin., 14 I ff. 38-38v).

51. «En la China al presente tienen ya tres residencias con seis padres y cuatro hermanos contando dos para los cuales envío ahora licencia para recibir en la Compañía...» (Ib. f. 38v).

52. «[...] que usan ellos con otros mandarines grandes y les dan las respuestas de sus visitas yendo ellos mismos a visitarlos a sus casas y convidándolos a las suyas como si ellos también fuesen mandarines...» (Ib. ff. 38-39v).

53. «Y con esta conversación mística pudieron comenzar a comunicarles y tratarles de las cosas del cielo, de la inmortalidad de las ánimas, de la otra vida y de diversas cosas humanas con que ellos quedan espantados teniéndolos por hombre de grandes letras y de santa vida» (Ib. f. 38). 
que los padres necesitaban adquirir más credibilidad de cara a los funcionarios y letrados chinos (Malatesta 1991: 52). De esta forma, y con ayuda de sus compañeros, el Visitador empezó a planear la mejor forma de homenajear al rey, ${ }^{54}$ dado que, todo estaba en manos del jefe del gran imperio. ${ }^{55} \mathrm{Al}$ igual que ocurrió con la embajada agustina de Felipe II al emperador de China entre 1575 y 1582, Valignano pensaba en enviar emisarios no «aristócratas con rango diplomático, como cabría esperar de una embajada al uso, sino religiosos» de la Compañía de Jesús. Por otra parte, el jesuita italiano era consciente de que la «Monarquía Católica [...] buscaba consolidar su posición en el Pacífico» así como de «los esfuerzos de ésta por proyectar una visión moldeada y trabajada de su propio imperio ante el mayor poder político de Oriente» (Carrió Invernizzi 2006: 62-64). De manera que una delegación europea - como solía ocurrir en Asia «abandonaba el estereotipo de un alto personaje» $\mathrm{y}$ "conferida a un diferente tipo de individuo, menos relevante, menos convencional, incluso francamente exótico»- era la única alternativa que podía resultar decisiva. Por otra parte, era improbable que el rey católico entrara en Oriente lejano y abriera «por fuerza esta puerta» de China. Consciente de que los jesuitas no podían encargarse de asuntos profanos, aunque, como afirmó Valignano, no faltarían «seculares y religiosos que lo propongan a su majestad», el Visitador y los padres decidieron actuar con astucia. La petición consistió en que desde Roma les enviasen al rey de China "por vía de embajador o de visita un presente», convencidos de que "con la codicia de él se moviesen los mandarines». Cada regalo tenía que adaptarse a la costumbre del país de llegada y buscar la manera adecuada y cuidada que los jesuitas habían mantenido hasta aquel momento. Asimismo, era imprescindible, según los misioneros, que los embajadores europeos fueran tratados «como conviene a la persona del papa» por las autoridades imperiales.

El primer intento de embajada del rey de China fue organizado por el Padre provincial de la India, el portugués Antonio de Quadros. Conforme a los comentarios de Valignano, este proyecto falló por culpa del «modo» con el que se organizó; de ahí que esta delegación no llegara a tener ningún tipo de repercusión en la misión de China. ${ }^{56}$ Partiendo de los supuestos anteriores, el Visitador decidió

54. «Es verdad que el rey de la China suele admitir dos maneras de embajadas, la una de estos reyes de acá como son los de Sion, de Camboya, de Pegú, de Malaca etc. y a estos trata con poca honra de la manera que se ha dicho, y otras recibe de los reyes de los tártaros que están en la frontera de Pekín y recibían en otros tiempos del Dairi cuando era universal rey de Japón» (ARSI, Jap. Sin. 11 I, f. 6). 55. Pasquale D’Elia, «Alessandro Valignano..., Op. cit., p. 131.

56. «El primero era que las cosas que venían en este presente, aunque valían mucho en Portugal, entre los chinos no eran de ninguna estima, porque no eran acomodadas a su uso y, así, aunque vino a propósito de Cantón un mandarín grande para ver el dicho presente, las cosas no le contentaron y por eso no hizo de ellas ningún caso. El segundo yerro fue que venía por embajador un hidalgo bien acompañado con su nao, la cual venía para cargar y mandarla cargada de mercaderías para la India y la una cosa y la otra hizo gran daño porque los mandarines como son tan sospechosos y enemigo de gente..." (ARSI, Jap. Sin. 11 I, f. 3v). 
encomendar a Michele Ruggieri, quien en este periodo vivía con Matteo Ricci en el interior de China, la labor de volver a Roma y estructurar la nueva embajada con los regalos necesarios al rey oriental. ${ }^{57}$ No hay que olvidar que fue el jesuita de Spinazzola quien tuvo por primera vez la idea de enviar una embajada de la Santa Sede a China (Spence 1984: 179-180). En dos cartas con un margen de varios años entre ellas (1581 y 1586), Ruggieri envió una petición al general Everardo Mercuriano y, posteriormente, al sucesor Claudio Acquaviva. ${ }^{58} \mathrm{~A}$ todos ellos el italiano les llevó en tres ocasiones algún presente, de acuerdo con la costumbre china, con el fin de establecer relación con los funcionarios de la administración local de Cantón. Así, tras ser recibido por el haidao, es decir, el responsable de seguridad de la costa, Ruggieri le regaló un reloj mecánico. Al ver su reacción de sorpresa, el jesuita intuyó que estos objetos llamaban la atención de los chinos; sin embargo, este desconocía que en este período en la tierra de Confucio ya tenían un buen conocimiento de los relojes mecánicos (Fontana 2005: 34-35).

Junto con Ruggieri, Valignano envió a Roma: «varie cose al Papa et al Re di Spagna di questo regno della China, tra le quali era una Descritione universale di

57. El porqué Valignano decidió sacrificar Ruggieri sigue siendo una de las incógnitas de la misión en China. Según Matteo Ricci, el padre Ruggieri «era già vecchio, e non poteva imparare la lingua cinese, pigliò questa buona occasione di mandarlo a Europa: perciochè, essendo stato tanti anni in queste parti, oltre quello che nelle lettere si scriveva al Papa, al Padre Generale et altri per promuovere questa opra, poteva come testimonio di vista, raccontare altre cose che venissero a proposito". Matteo Ricci, Storia dell'Introduzione del cristianesimo in Cina scritta da Matteo Ricci S. I. Nuovamente edita e ampiamente commentata col sussidio di molte fonti inedite e delle fonti cinesi da Pasquale M. D'Elia S. I., Libreria dello Stato, Roma, 1942, p. 250. Sin embargo, en la misma obra el padre D’Elia afirmó en la nota n. 2 que la expresión de Ricci fue «impropria» ya que Ruggieri, nacido en el año 1543, no era tan viejo. Por otro lado, Valignano, en una carta del 26 de noviembre de 1588, afirmó: «el padre Miguel Rogerio tiene trabajado mucho en esta misión y ahora, llegando a Roma, parece que es razón darle algún descanso; cuanto más, que él se va haciendo ya viejo y muy cargado, y con esta jornada tan larga, lo quedará más; y, allende de esto, no tiene buena pronunciación en la lengua; $y$, por esto, parece que V. P. lo debe excusar de tornar a enviar aquí, pues esta misión no es para hombres viejos y cansados, y harto habrá hecho para bien de esta misión con llegar ahí» (ARSI, Jap. Sin. 11, 29v). De todas formas el debate sobre la escasa sintonía de los dos sigue todavía abierto.

58. El 12 de noviembre de 1581 escribía: «S’io fusse a Roma havriame da ponere avanti li piedi di Sua Santità, la quale molto ben so quanto desidera questa impresa di Cina e la Conversione di questo gran regno, e gli domandarebbe questa gracia che me desse una carta solamente per il re di Cina di credenza, e piena d'amor paternale, chiedendogli che mi desse licentia per predicar a sua gente e insegnar questa dottrina a chi la volesse recevere senza fargli forza alcuna [...]». Sucesivamente, el 8 de noviembre de 1586, escribió: «Le cose che potrebbe mandar Sua Santità o Sua Maestà, per via nostra, al re della Cina non hanno de esser di molto valore, se non cose che in questo regno non ha; como a dir alcunj braccj de coralli finj, che il re face grande conta per il suo studio, uno libro della Bibbia miniato e bello di figure, guarnito di velluto e oro, alcunj orologij piccoli e grandi doratj. Uno struzzo vivo sarebbe meraviglioso presente per il re della Cina, perchè appreza molto le penne di quello, e una cosa viva di animal o passaro, che qui non ha, è di grande stima; alcune imagini nostre della sacratissima Virgine o di nostro Signore \&c.» (Venturi 1911: 403 y 449). 
tutta la Cina, fatta a guisa che qua si suole chiamare gueipini $[\ldots] » .{ }^{59} \mathrm{Y}$ es que a causa de varios problemas en la navegación en la isla Terceira (perteneciente a las islas Azores), una parte de los regalos chinos se perdió antes de zarpar en Lisboa. ${ }^{60}$ No obstante, el documento clave de todo el material que se envió a Roma se salvó, es decir, el Memorial de las cosas que han de venir para el presente que S. Santidad ha de enviar al Rey de la China. Se trataba de un listado detallado de los dones que era conveniente preparar para agasajar al rey de China, que, a su vez, tenía que ser entregado en la Santa Sede. Es oportuno transcribir aquí al menos la Suma de los veintiséis presentes que se incluyeron en el penúltimo folio de este Memorial:

1. Es necesario el aparato para que allá se estimen las cosas.

2. La manera de menear y escribir la carta del papa.

3. La manera de cerrar y cubrir la carta, y sobrescribirla y de su caja.

4. La Manera del cubrir la carta para el tutan y dos privilegios que aquí se piden.

5. Un testamento nuevo escrito muy bien y meneado que será el punto principal y cubierto.

6. Tres cintos para el Rey, que también es menester mucho tiempo para hacerse.

7. Tres carapuças y coronas y con sus bolsas, y [tiempo para tal menester].

8. Tres ramos de coral rojo.

9. Una mesa de varias piedras.

10. Cinco piezas de varios brocados ricos.

11. Unos beobus, como aquí se dice largamente.

12. Dos espejos de cristal.

13. Cinco virles o vidrios triangulares.

14. Doscientos vidrios y de ellos de figuras de leones y dragones puntados.

15. Dos o tres estuches de con diversos peines.

16. Una docena de relojes de arena.

17. Un reloj de sobremesa [de hierro] mayor que el que nuestro padre envió.

18. Un globo celeste y otro terrestre muy bien hechos.

19. Libros de arquitectura.

20. Libros de animales y montería, y uno de papas y otro de lo de temporal.

21. Algunos cuadros grandes de imágenes del crucifijo y otras.

22. Retratos de Roma vieja y nueva bien iluminados.

23. Plumas de colores grandes.

24. Dos docenas de candados que se abren por letras.

25. Un órgano y un clavicordio muy ricos.

26. Todo esto se debe procurar, mas si algo faltase, no sea esto nuestro. (ARSI, Fondo Gesuitico, 772.2 (bis), ff. 1-9).

59. «[...] di molti cuadretti attaccati insieme, che si stendono in piedi nelle sale e fanno il campo uguale, e si possono poi doppiare e raccogliere uno sopra l'altro; cosa che al Re di Spagna aggradò molto et anco al Papa. Vi era anco la forma della corona e veste regia del Re della Cina e degli altri magistrati principali» (Ib. p. 250).

60. Ib. p. 251, nota 1. D’Elia describe detenidamente todo el viaje de regreso a Europa de Ruggieri. 
Cada petición de este documento se describió y aclaró detenidamente en los folios anteriores a este listado con la siguiente recomendación:

[...] y no se espante V.P. de pedirnos tantas cubiertas y ceremonias para esta carta, porque cuanto más de esto lleva tanto más será tenido en cuenta de los chinos y adonde hay tan poco conocimiento de la majestad pontifical. (ARSI, Jap. Sin. 11 I, f. 5)

Como analizó correctamente la estudiosa Elisabetta Corsi, insistiendo en el valor educativo y persuasivo de las imágenes en la misión, la importancia y el uso selectivo de las representaciones en la descripción de este listado fue fundamental en cuanto ars rethorica adoptada por los padres (Chinchilla y Romano 2008: 8789 y 99). El punto veintiuno es el ejemplo concreto en el que se vislumbra que los jesuitas confiaban obtener el interés por parte de los chinos mediante la universalidad de las imágenes y los gestos. ${ }^{61}$ Valignano subrayó que era preciso evitar las imágenes cruentas, como la de la Pasión de Jesús, ya que, en la China moderna se aborrecía la «representación de cuerpos desnudos y ensangrentados». Pero toda la información contenida en este informe se extravió y volvió a aparecer en otra carta del Visitador. Como si no bastara con el Memorial, Valignano reescribió acerca de ello en una misiva desde Macao el 10 de noviembre de 1588. Esta vez el italiano se centró más en los problemas lingüísticos de estas veintiséis peticiones, en particular de las cartas escritas por Ricci "con un grave letterato di Sciaochino» (Ricci 1942: 249) que tenían que ser dirigidas al rey de China, y de las patentes en «lengua y caracteres chinos» con su respectiva versión en latín. ${ }^{62}$ Todo debía ser traducido a la manera que «más cuadrase al entendimiento por orejas de los chinos» y, después, ser impreso para una adecuada presentación. ${ }^{63}$

61. «21.Ítem algunas imágenes grandes y enteras pintadas ricamente en olio de algún insigne pintor como un Jesucristo nuestro Señor muy glorioso, rodeado de muchos ángeles y una Asunción de nuestra Seńora muy perfecta y gloriosa con su nińo en los brazos o se pinte de otra manera [empie] con su niño Jesús en los brazos rodeada de ángeles y muy gloriosa» (ARSI, Fondo Gesuitico, 772.2 (bis)). Pero, ¿cuál era el verdadero valor de estas imágenes? Corsi lo explicó muy bien a través de unas series de preguntas que acaban en una respuesta abierta, según el punto de vista que se adopte. Ib., p. 97.

62. "También van escritas dos cartas y dos patentes. La una es para el rey de la China y en esta solamente se ha habla y declara el misterio para cual los padres son enviados que es para les enseñar verdadera doctrina, declarándose que este oficio pertenece a S. Santidad [...] De las patentes una sea hecha para los padres, no tanto porque se hayan de servir de ella ni mostrarla por las partes de Europa cuanto para mostrar aquí a los mandarines así para que entiendan que el sumo Pontífice que envía a los padres es persona de grande autoridad pues por su potente encomienda a todos los reyes de Tienchocon [...] La otra patente va por los mandarines que el rey quisiese enviar para Europa, no porque no parezca que se haya esto por ahora de efectuar, mas para los convidar y con esto juntamente darles a contender la grande autoridad que $S$. Santidad tiene para a todos los reyes como también para los más asegurar pues convidándolos aun a nuestras tierras se les dan ocasión de quitar toda sospecha...» (ARSI, Jap. Sin. 11 I, f. 4v-5).

63. "Mas porque tenemos mucha dada que esto no se sepa allí hacer y que variando la letra cualquier cosa no se podrá aquí leer, procurando de tomar otro remedio y es hacer escribir en tablas 
En esta misiva, Valignano explicó incluso algunos conceptos de adaptación e interpretación del chino, como los «nombres propios de los padres» ${ }^{64}$ o la palabra 'Tienchocon' cuyo significado se tradujo por 'reino del cielo', que era el término con que los padres fueron reconocidos en Zhaoqing. A partir de estas percepciones sobre este término, los misioneros fueron considerados como los promulgadores de la santa doctrina del reino de 'Tienchocon' ${ }^{65}$ Con este informe, el listado no volvió a ser mencionado por el padre Visitador durante unos años y, aparentemente, cayó en el olvido.

Tras todas estas actuaciones, el 18 de octubre de 1598 otro jesuita, el italiano Niccolò Longobardi (Caltagirone, 10 de septiembre de 1565 - Pekín, 5 de septiembre de 1654), volvió a pedir al general de la Compañía libros e «imágenes, con el fin de consolar y ayudar a los cristianos». ${ }^{66}$

Dos años más tarde, el 21 de octubre, desde Nagasaki, Valignano volvió a redactar otro documento imprescindible para entender los objetivos y los porqués de este requerimiento que, según algunos investigadores, nunca llegó a cumplirse. Tal vez, las exigencias a la embajada fueran una manera de encontrar más apoyo tanto en la Santa Sede como en el imperio cristiano, así como un modo para tutelar el fervor «dañino» de los frailes, una vez obtenida la primacía de la misión en China. ${ }^{67}$ Otra de las razones fue, sin duda, la insuficiencia de dinero que tenía el Colegio de Macao que también sustentaba todas las institu-

las dichas cartas y patentes y mandar con el padre Rogerio las dichas tablas para que por ellos puedan imprimir en lo quisieren las dichas patentes y cartas y enviarlas escritas como se ha dicho en pergamino en letras de oro [...]» (ARSI, Jap. Sin. 11 I, f. 5).

64. "También nombramos, con ciertos y señalados nombres propios, los padres que han de venir porque en la China ni se pueden escribir y pronunciar por ellos todos nuestros nombres, ni todos escritos por sus letras» (ARSI, Jap. Sin. 11 I, f. 4v).

65. «Es reino donde hay santa doctrina y donde se salvan las almas y que en él usan de una agua santa de mucha eficacia y virtud y dicen también en sus libros que en este reino se hacen muy hermoso [vidrios] y hay muy grandes caballos y van los hombres con largos vestidos y mangas largas y grandes con sus calzones, medias calzas y zapatos y que las mujeres llevan un largo velo en la cabeza y que los hombres de estos reinos son limpios y que está en las partes de Occidente, muy lejos de la China, y añaden aún algunos que en tiempo antiguo vinieron de este Tunchocon algunos padres santos a la China». "Tienchocon se escribe con tres letras. La primera de la cual se llama 'Tien', que quiere decir 'cielo', otra que se llama 'Con', que quiere decir 'reino' que es la derradeira y la tercera que es la del medio llamada 'Cho', parece conforme a lo que los padres dicen que no tiene significación más que $[\ldots]$ con que esta palabra se pronuncia y se escribe y así parece que quiere significar 'reino del cielo'» (ARSI, Jap. Sin. 11 I, ff. 4-4v).

66. Ib. 87-88. ARSI, Jap. Sin. 13 f. 117a.

67. «Da missão da China escrevo táo bem largamente a N. P. que me ocurre e se quisemos que vá adiante se há de procurar em todo caso que por uma parte se terem estorvos que nos podem causar os frades com o demasiado e pouco natural fervor de entrar na China, em tempo que bem se entende que não podem causar se não estorvo, parte com procurar de abrir-nos mais esta porta e dar para com aos mandarins alguma autoridade aos padres que hão de [publicar] nossa lei santa com os meios que escreveu a N.P. e por sem dúvida tenho que vindo a efetuar-se este negocio de presente embaixada». Macao 28 de octubre de 1588 (ARSI, Jap. Sin., 10 II, ff. 331-331v). 
ciones jesuitas de China. ${ }^{68}$ El remedio que recomendaron los padres fue pedir al papa «algunos padres nuestros con una embajada y con un buen presente al rey de la China de algunas piezas curiosas y ricas que él pueda estimar en que S. Santidad gastase hasta 5 o 6 mil ducados». ${ }^{69}$ Hay que subrayar que la importancia de esta embajada fue patente ya en la carta de Valignano del 21 de noviembre de 1588. En ella, el Visitador expuso siete buenos motivos para mandar a China esta delegación con el supuesto «regalo»y, al mismo tiempo, aclaraba cualquier tipo de duda planteada por los desertores de esta misión. ${ }^{70}$ Ahora bien, aunque en la misiva de 1588 el jesuita italiano discurrió acerca de las posibles dificultades de la embajada y de los regalos al rey de China, ${ }^{71}$ en otro

68. «[...] el rector del colegio de Macao que tiene también a su cargo las residencias de la China no teniendo para poderlas proveer pues ni aun aquel colegio tiene fundación y se sustenta parte de limosnas, las cuales con la pérdida del junco son ya muy pocas por la grande pobreza en que quedó toda aquella ciudad, y parte con lo que se le da de eso poco que Japón tiene» (ARSI, Jap. Sin., 14 I ff. 38v-39).

69. Ib. f. 39

70. «[... la primera es que por saber S. Santidad la dificultad que hay en ser esta embajada admitida por los mandarines y la duda si serán los embajadores tratados como conviene puede causar mayor dificultad en se resolver [...]. La segunda es que puede parecer mucho gastarse cinco o seis ducados en este presente que tanto podrán estar las cosas hechas conforme a lo que se escribe en el memorial, y también podrán parecer extrańas algunas cosas que se piden y superfluo el gasto que se ha de hacer en las caxiñas y conciertos, a lo cual digo que se considerare cuan grande son las riquezas de rey de la China y cuan necesario es que parezca lustroso y rico a los ojos de los chinos lo que se enviare [...]. La tercera es que [...] mas con todo cuidado y diligencia se ha de procurar que vengan todas las cosas que van escritas en el memorial con la forma y concierto que en él se escriben, y las cosas todas sean muy bien hechas...y paréceme esta embajada, y presente de tanta importancia y tan único medio, que si no fuera grande pérdida que tuvo ahora Japón me atreviera pedir a V. P. que alcanzando de S. Santidad lo que quisiese dar para esta embajada [...]. La cuarta cosa que ha V.P. de advertir que el fraile Martin Ignacio fue también con esta intención de tratar con el rey que enviase un presente a la China, mas no sé lo que hará en eso porque años ha que se habla de este presente que al rey enviaba [...]. La quinta cosa es que puesto que trabajamos mucho para hacer la carta de S. Santidad para el rey de la China, a nuestro modo nunca hubo remedio poderse trasladar en lengua china si no conforme a sus frases acostumbradas porque ni todas las cosas y palabras que nos decimos se pueden bien trazar en lengua china ni nuestras frases son para sus orejas acomodas [...]. La sexta cosa es que el obispo de la China que aquí está dice que escribe a S. Santidad quejándose porque no le queremos dejar ir a Japón y el fraile Martino Ignacio fue con la misma intención de tratar sobre esto con S. Santidad [...]. La última cosa es que envió a V.P. por el padre Rogerio unos mapas que aquí llaman Beobus, semejantes a los otros que llevaron los caballeros japoneses a Gregorio XIII de santa manera, mas en estos va la descripción de la China, de la manera que se sacó con mucha diligencia de sus libros, y aunque esta fue obra se hizo ahora de prisa, creo todavía que holgarán de verla en Roma [... ]» (ARSI, Jap. Sin. 11 I, ff. 13-14v). 71. «La primera es acerca del gasto que en esto se ha de hacer que se divide en dos partes; la una es acerca del presente que se ha de enviar que en nuestra cuenta parece que podrá valer así poco más o menos de cuatro mil ducados, la otra es del modo con que se han de sustentar los dichos padres en la China, y llevar esta misión adelante [...]. La segunda dificultad es la duda e incertidumbre que aún ha en ser los padres admitidos para ir con este presente al rey de la China, porque como ellos son tan sospechoso y [percatados] y no tienen ningún conocimiento de la calidad de S. Santidad, puede ser que no les quieran dar entrada ni escribir al rey que vivieron aquí y rehacen el presente y la em- 
escrito inédito de 1600 que se verá a continuación, Valignano pareció cambiar radicalmente de idea. En esa ocasión, el Visitador expuso al general de la Compañía, Claudio Acquaviva, las razones para anular de inmediato esta decisión. Sobre ese asunto, el jesuita dejó el mensaje abierto a la decisión del papa, ${ }^{72} \sin$ embargo, presentó tres razones en contra de la embajada. La primera parece poco clara y repetitiva:

[...] la primera porque el fin que se pretendía con esta embajada era acuditar los padres con el rey y con los mandarines para que pudiesen tener entrada mayor en la China y algún crédito y reputación con ellos y pues vemos que nuestro Señor por si él mismo le fue dando este crédito y esta entrada parece que se puede excusar pedir esta embajada a S. Santidad que tienen tantas dificultades así para enviarse, como para ser recibida como se escribió pues ya tenemos alcanzado lo que con ella pretendíamos. ${ }^{73}$

Por el contrario, el segundo y tercer motivo son más nítidos:

La segunda razón es porque el procurar de venir esta embajada ha de hacer por Europa y por la India mucho estruendo y cuanto primero parecía que nos podía ayudar para alcanzar este fin que pretendíamos en la China, tanto parece ahora que nos podría estorbar y poner esta misión en peligro porque teniéndonos otros ya alcanzados por la merced de Dios este fin que pretendíamos recibiendo los mandarines a los padres con simplicidad como hombres letrados y santos, puede ser que viendo ahora venir la embajada de S. Santidad para el rey de la China y entendiendo que los padres que ahora ahí están fueron enviados por el papa y que le avisan de las cosas de la China. [...] La tercera razón finalmente es porque debemos excusar cuanto se puede de hacer en el [modo] estruendo, especialmente en cosas inciertas y que puedan salir mal, y esta embajada es cierto que si se alcanzare ha de hacer por el mundo grande estruendo y puédenos salir mal, porque puede ser mal recibida y estorbar lo que ahora vamos haciendo sin estruendo. [...]. Por eso digo que me parece que se excusa y que en lugar de Embajada se deberían pedir a S. Santidad algunas piezas curiosas de las que enviaron a pedir para que los padres por sí mismos $o$ en nombre del superior que tienen en Macao las fuesen presentando a las ocasiones que se ofreciese al rey de la China y a los colaos y a otros grandes mandarines. (ARSI, Jap. Sin., 14 I ff. 39-39v.)

bajada, como lo hicieron otras veces como arriba dijimos, más aunque esto puede ser, más probable nos parece el contrario [...]. La tercera dificultad es acerca del modo como han de ser estos padres admitidos porque son ellos tan soberbios y hacen, como se ha dicho, tan para cuenta de todos los reyes de las más partes que los embajadores que a ellos son enviados de los reyes [comarcanos], son tan bajamente recibidos que los hacen estar de rodillas delante de todos los mandarines mostrando siempre muy para cuenta de ellos, porque como están en su tierra ricos y abastados, sin tener necesidad de ningún comercio de otras tierras [...]» (ARSI, Jap. Sin., 11 I, ff. 5v-6).

72. «Decidirá S. Santidad que mande esta embajada por las razones siguientes» (ARSI, Jap. Sin., 14 I, f. 40).

73. Ib. f. 39. 
Finalmente, Valignano concluyó su misiva afirmando que la embajada no era necesaria, teniendo en cuenta lo que se había alcanzado sin ella y por temor al posible alboroto que generara y estropeara la empresa. ${ }^{74}$ Por ello, resulta claro que el Visitador pidiera un año más tarde, el 2 de marzo de 1601, desde Nagasaki, solo un "remedio temporal para sustentar los padres que están por la China", sin la embajada, y su listado de regalos para el rey (ARSI, Jap. Sin., 14 f. 63). Esto se debió en parte a que en el Colegio de Macao los jesuitas quedaron sin "fundación ni renta» y la misma institución se encargaba de "sustentar los padres y las residencias que están por la China adentro» (ARSI, Jap. Sin. 14 I f. 81).

Cabría preguntarse si es verdad que los regalos que se enviaron al rey de China, pedidos en el famoso Memorial, no llegaron nunca al destino y quedaron como un simple listado. ${ }^{75}$ Esto no parece tan cuestionable. Cabe señalar también que en 1600 los navíos de Olivier Van Noort atacaron Manila, y sucesivamente, en 1601, Jacob Van Neck (1564-1638) penetró en aguas asiáticas con una flota que asoló nuevamente la capital, tras lo cual bloquearon el puerto de Macao. Por otro lado, con solo considerar la misiva de Valignano desde Macao el 12 de noviembre de 1603, parece que el rey no solo recibió los regalos, sino que los llegó a poner incluso en su habitación:

Porque aunque el rey no le haya hasta ahora dado ningún despacho, todavía sabe que están en Pekín y recibió su presente y nuestro holgar grandemente con las imágenes o relojes y clavo que le dieron e hizo que algunos de sus cortesanos aprendiesen de los nuestros a tañer clavo y atemperar los relojes y los tiene en su cámara y para enseñarlos fue uno de los nuestros padres muchas veces a palacio y aunque él no vio al rey parece que con disimulación fue visto de él. (ARSI, Jap. Sin. 14 I, f. 140v).

¿Eran «las imágenes o relojes y clavo» a los que se refiere en esta carta los mismos objetos que se citaron en el listado del Memorial: ${ }^{76}$ Probablemente sí, considerando la fecha posterior al listado. El estudioso Po-Chia Hsia también está de acuerdo con la llegada de estos regalos que Valignano preparó y reenvió a

74. También el padre Pasquale D'Elia afirmó que, hasta el año 1600, Valignano insistió con esta idea, y al año siguiente, cuando Ricci partió para Pekín, el Visitador cambió de idea. El estudioso italiano llegó a dar una conferencia sobre esta embajada, que al parecer no se publicó y todavía está mecanografiada en el Archivo de la Università Gregoriana en Roma (D’Elia 1941: 131)

75. «For all the care that had gone into compiling it, the Jesuits' shopping list was to remain just a list. Ruggieri never returned to China, but passed the rest of his life in Italy, where he lectured to would-be missionaries and recorded aspects of his life and travels» (Laven 2011: 102). "As sucessivas mortes de quatro Papas e outros obstáculos dissuadiram finalmente o Geral de ir mais longe com este projecto» (Cf. Malatesta 1991: 52). "L'ipotesi di inviare un'ambasciata papale all'imperatore - per preparare la quale Ruggieri era partito quasi dieci anni prima - era tuttavia definitivamente sfumata e anche il generale Acquaviva aveva desisitito» (Fontana 2005: 149).

76. No hay que olvidar que incluso Matteo Ricci en su Storia della missione describió un reloj mecánico, otro que le regaló el arzobispo de Manila, un cuadro de la Virgen realizado en España y una pintura italiana que retrataba un Jesucristo (Cf. Fontana 2005: 150). 
Ricci desde Macao. El jesuita de Macerata creyó desde el principio que esta fue una tarea desalentadora, ya que la ley Ming prohibía cualquier tipo de viaje no autorizado a Pekín, en particular, si se percibía intervención política sospechosa. ${ }^{77}$ Es posible que el propio Ricci fuera quien donase estos regalos al rey, como bien se percata en otro Memorial al rey redactado en lengua china por el jesuita de Macerata en 1600. Este listado propone solo dieciséis regalos, a diferencia de los veintiséis que se encuentran en el detallado escrito de Valignano (Ricci 2001: 282-284). Sin entrar demasiado en la comparación, es evidente que la base de los dos escritos es, en esencia, la misma, aunque las variaciones son contundentes. En el Memorial de Ricci también hay imágenes de la Virgen (punto 21 del listado de Valignano), el Nuevo Testamento (5), los relojes (17), los prismas (13), el clavicordio (25), los biombos (11), los brocados (10) y los espejos (12). No obstante, Ricci optó por llevar a cabo modificaciones específicas que merecen otro tipo de estudio.

Volviendo atrás, Valignano visitó Macao por cuarta vez el 24 de octubre de 1592 hasta, probablemente, el 15 o el 16 de noviembre de 1594. En estos años, el Visitador pudo conversar con Matteo Ricci sobre diversos asuntos de la misión, como la adopción definitiva del estilo y las costumbres de los letrados chinos, autodefiniéndose como "predicadores instruidos» (Malatesta 1991: 53-54). Transcurrió muy poco tiempo entre la cuarta y la quinta estancia en Macao (desde el 20 de julio de 1597 hasta el 14 de julio de 1598). Durante ese intervalo, Valignano llegó a ser nombrado Visitador de la India y Japón. La última estancia del jesuita en Macao fue desde el 10 de febrero de 1603 hasta el 20 de enero de $1606 .{ }^{78}$ Precisamente, en 1603 , las tres residencias "por la China adentro" contaban con seis padres y cuatros hermanos chinos que vivían "en tres ciudades principales de tres provincias con mucho crédito y reputación». Quizá, decepcionado por la falta de interés por parte de la corona de Portugal, Valignano volvió a escribir acerca del memorial al cardenal Belarmino. Una vez más, el Visitador no mencionó los regalos al rey de China:

Y, por su orden, se ha dado memorial al rey de España en que se le pide que quiera fundar aquel colegio y proveer también los padres que están por la China adentro conforme a la obligación que tiene como señor de esta navegación y conquista que heredó con la corona de Portugal. Pero no tenemos hasta ahora nueva del despacho

77. El investigador, acerca de la llegada de los regalos, afirmó las siguientes frases sin precisar la fuente primaria: «Travelling quicky, Cattaneo and a new Portuguese missionary, João da Rocha, arrived in Nanchang two days ahead of Wang. Alerted of this new opportunity, Ricci made preparations. He paid Wang a visit, upon the latter's arrival. Telling the mandarin of his ardent desire to offer gifts of tribute to the emperor, Ricci showed Wang the precious commodities he had received from Macao: two European clocks, a painting of the Savior, and a Venetian prism. The last item Ricci presented as a gift to persuade Mandarin Wang; to this Ricci added the overwhelming gift of a clock to clench Wang's goodwill» (Po-Chia Hsia 2010: 169-170).

78. Ib. p. 55 . 
que ha dado. Mas como estas cosas pasan por manos de tantos oficiales y consejos y son partes tan remotas, la experiencia maestra que se concluye muy despacio y con dificultad, y entre tanto el gasto corre y los padres y las misiones padecen. (ARSI, Jap. Sin. 14 I, f. 81)

Durante estos años al padre Visitador le inquietaba sobre todo la situación en el Colegio de Macao por estar «a cuenta de Japón», por gastar cada año «más de mil ducados con los sujetos de Japón que están allí estudiando» y, también, porque la misma institución sufrió en aquel periodo un gran accidente por causas naturales (ARSI, Jap. Sin. 14 I, f. 140v). De hecho, en la consulta de la India de diciembre de 1575 en las Resoluciones del Padre Visitador, Valignano y sus compañeros decretaron que «se debía hacer Japón provincia apartada, incluyendo solamente la China» (Valignano 1998: 295). Cinco años más tarde, este asunto fue uno de los puntos de la consulta japonesa en Bungo (octubre de 1580). En ella se reunieron veintidós padres y la mayoría, al igual que Valignano, estaba de acuerdo en independizar la provincia de Japón, desde el punto de vista económico, del personal de la misión, de la supervisión y la autonomía de Macao (Schütte 1985: 226-227). A tal respecto, el 26 de noviembre Valignano redactó una larga misiva en la que trazó un balance de la situación económica en China, desde la "primeira provisão" que los jesuitas recibieron en Macao en 1597 por Matías de Alburquerque hasta el último abastecimiento de Europa. ${ }^{79}$ Acerca de su primera disposición en Macao, en la que trató de sustentar el instituto con el comercio de la seda, discurrió también en su Apología:

Y así llegado aquí a Macao, el año de 1578, y informándome de lo que pasaba acerca de esto, y entendiendo que por entonces no era posible excusarse este medio, y juntamente viendo el grande peligro en que estaban los Padres y cristiandad de Japón, por no tener cierta y suficiente renta para tan grandes y continuos gastos como necesariamente se hacían, procuré con Su Santidad y con Su Majestad, por vía de nuestro Padre General, que se le diese algún remedio y traté también con esta ciudad de Macao sobre que este empleo de seda se hiciese de cierta y determinada cantidad con su voluntad y beneplácito, para que quedase como una renta cierta, de manera que no hubiese en ellos mudanza y se hiciese con la moderación debida y satisfacción del pueblo. (Valignano 1998: 191)

El jesuita italiano estructuró el sustento para las residencias chinas de la Compañía apoyando al rector del Colegio de $\mathrm{Macao}^{80}$ de manera que en el in-

79. Jap. Sin. 14 I, ff. 149-150v. Macao 26 de noviembre de 1603. Carta acerca dos ordenados da China escreveu-a o padre Alexandre Valignano... Cf. Carta do padre Alexandre Valignano acerca dos ordenados da China por o [Provincial] de Goa...

80. Unos años más tarde volvió a repartir el dinero para sustentar la misión en China: «Para a China se há de mandar este ano logo que chegarem as naus de Japão até mil e trezentos ou mil quatrocentos [reais]. Seiscentos até setecentos a residência de Paquiem para haver com que pagar 
terior de China los padres pudiesen vivir de forma independiente del puerto portugués (D’Elia 1941: 134). Esta decisión tan drástica de apartar de esta misión la supervisión del Colegio de Macao significó que Matteo Ricci llegara a ser directamente el superior de la Compañía en China y la Provincia de la India. Tras dar al italiano de Macerata plena autonomía institucional, Valignano despachó a un grupo de sacerdotes, al italiano Alfonso Vagnone (1568-1640) y a los portugueses Pedro Ribeiro (1570-1640) y Gaspar Ferreira (1571-1649) a Nankín para empezar los estudios chinos (Brockey 2007: 55).

Cabe señalar que la situación económica tanto del Colegio de Macao como de las residencias en China se solucionó con la llegada de la nave y las provisiones en $1605 .{ }^{81}$ Ese mismo año entre las cuatro residencias de la Compañía de Jesús en China se repartieron dieciséis padres «todos theologos europeos e cuatro irmãos chinas»" ${ }^{82}$ Por otro lado, la importancia de este instituto fue incuestionable y, como afirmó en una de sus últimas cartas el padre Visitador, el «fruto que se ha sacado de él en los ocho años después que se edificó fue haberse proveído toda esta viceprovincia de grande número de letrados y teólogos». ${ }^{83}$ En los últimos años, antes de su muerte, Valignano pareció ser más satisfecho en relación con la situación en el interior de China; el jesuita veía crecer «el número de las casas y de la gente y gasto sin tener con que se sustentar que para mí no es cosas de pequeño cuidado». ${ }^{84}$

Finalmente, pocos días después de que Alessandro Valignano decidiera partir para el hinterland chino con el fin de visitar otros misioneros, el jesuita italiano murió en Macao el 20 de enero de $1606 .{ }^{85}$ Según afirmó en una de sus últimas misivas, tenía pensado ir acompañado por el padre Lázaro Cattaneo y, a la vuelta, enviar a los jesuitas Francisco López y Sabatino de Visis. ${ }^{86}$ Valignano

as dívidas que fez com a compra das casas e para ter $\mathrm{cm}$ que se sustentar este ano. E o mais para se dar a cada casa seu particular ordenado da maneira que estava determinado, procurando de arrecadar cada ano o que alguns amigos prometeram para ajuda da residência da China». Lembrança que faz o Padre Visitador da China e Japão estando com grandes dores e fraqueza com perigo da acabar com ellas esta vida. Japón, 1606 (ARSI, Jap. Sin 14 II, f. 229v).

81. «E com esta nau também tivemos grande remedio com que pagamos aos chinos o que nos tinham dado fiado e tivemos com que sustentar este ano este colégio e residências da China...». Macao, 20 de enero de 1605 (ARSI, Jap. Sin., 14 II, f. 186v).

82. Macao, 15 de enero de 1605. Archivo de España de la Compañía de Jesús en Alcalá de Henares (AESI-A), Estante 2, caja 101, documento 23, leg. 1001. f. 1.

83. «[...] poder bastantemente entender la pérdida que hubo en el así por quemar por un desastre su iglesia y por la ruina que en la parte de la casa antigua hicieron el año pasado los tifones, como de la que hubo con la tomada de las naves por los holandeses». Ib. f. 140v. Esta carta se repite en: ARSI, Jap. Sin. 14 I, f. 162, Macao, 7 de abril de 1604.

84. Nagasaki, 24 de octubre de 1601 a Claudio Acquaviva (ARSI, Jap. Sin. 14 I, f. 83).

85. Este mismo ańo volvió a pedir otro «remedio que se ha de dar para cuatro residencias de China» en el Memorial das cousas que o padre Francisco Rodriguez procurador da Viceprovincia da China $e$ de Japão ha de tratar em Roma con nosso padre (ARSI, Jap. Sin. 14 II f. 272).

86. «Também eu tinha (como este dito) determinado de entrar pola China adentro juntamente com o padre Lazaro Cattaneo que havia de ir por meu companheiro e depois a tornada tinha determinado de mandar para a missão da China o padre Francisco López e ao padre Sabbatino 
quería visitar las tres residencia de Shaozhou, Nanchang e Nankín y llegar hasta la capital (Fontana 2005: 255). Sin embargo, antes de salir de Macao, sufrió un serio ataque de uremia, enfermedad que le venía afectando desde hacía unos años, y murió cuando aún no había cumplido los sesenta y siete años (Malatesta (1991: 55). De acuerdo con Andrew Ross, la misión jesuita en China se suele asociar con Matteo Ricci, sin considerar que sin Valignano no habría habido ningún Ricci. Como se ha demostrado, fue el jesuita de Chieti quien impulsó la instrucción y el aprendizaje de la lengua y cultura china a los misioneros, evitando, así, los primeros errores de la misión. Fue el Visitador quien ordenó a Ricci estudiar los clásicos chinos y transcribir los Cuatros libros de Confucio o Mencio. Además, autorizó definitivamente a los padres al cambio de la vestimenta y a toda una aproximación diferente a la manera de los literatos chinos (Ross 1999: 510-511).

de Visis por me parecer que tem vocação para esta missão e artes para poderem fazer nela muito servió a nosso Senhor por que agora parece que Deus há servido determinar bem por outra cosa a encomendo ao padre Rodriguez que quando comodamente puder mande a este dos padres para esta missão». Lembrança que faz o Padre Visitador da China e Japão estando com grandes dores e fraqueza com perigo da acabar com ellas esta vida. Japón, 17 de enero de 1606 (ARSI, Jap. Sin. 14 II, f. 229v). 


\section{Bibliografía}

Archivo Histórico de la Compañía de Jesús (ARSI), Fondo Gesuitico, 772.2 (bis).

Archivo Histórico de la Compañía de Jesús (ARSI), Japonica-Sinica.

Basto da Silva, Beatriz, Cronologia da História de Macau. Séculos XVI-XVII, vol. 1, Macau, Direcçáo dos serviços de educação, 1992.

Bernard, Henri «Valignani ou Valignano, L'auteur véritable du récit de la première ambassade japonaise en Europe (1582-1590)». Monumenta Nipponica, vol. 1, n. ${ }^{\circ} 2$ (Jul., 1938), 378-385.

Brockey, Liam Matthew, Journey to the East: The Jesuit Mission to China, 15791724, Cambridge, Belknap Press of Harvard University, 2007.

Carrió Invernizzi, Diana, Embajadores culturales: transferencias y lealtades de la diplomacia española de la Edad Moderna, Madrid, Editorial UNED, 2016.

Chan, Albert S.J., Chinese Books and Documents in the Jesuit Archives in Rome. A Descriptive Catalogue (Japonica-Sinica I-IV.), Nueva York, M.E. Sharpe, 2002.

Chinchilla, Perla y Romano, Antonella, Escritura de la modernidad. Los jesuitas entre cultura retórica y cultura cientifica, México, D.F., El mundo sobre el papel, 2008.

Confucio, The Four Books. [Sishu 四書. 1963], Guangming shuju 光明書局, Hong Kong 香港, 1963.

D'elia, Pasquale, "Quadro storico sinologico del primo libro di dottrina cristiana in cinese». Archivum Historicum Societatis Iesu, vol. III (193-222), 1934 , 193-222.

—, «Alessandro Valignano e l'introduzione definitiva del cristianesimo in China». La civiltà cattolica, 1941, 124-135.

Fontana, Michela, Matteo Ricci. Un jesuita alla corte dei Ming, Milán, Mondadori, 2005.

Gernet, Jacques, Primeras reacciones chinas al cristianismo, México, S.L. Fondo e Cultura Económica, 1989.

Hosne, Ana Carolina, The Jesuit Missions to China and Peru, 1570-1610. Expectations and appraisals of expansionism, Nueva York, Routledge, 2013.

Jami, Catherine, Engelfriet, Peter y Blue, Gregory, Statecraft and Intellectual Renewal in Late Ming China. The Cross-Cultural Synthesis of Xu Guangqi (1562-1633), Leiden, Brill, 2001.

LACH, Donald T., Asia in the Making of Europe, vol. I, Chicago, University of Chicago Press, 1965.

Laven, Mary, Mission to China. Matteo Ricci and the Jesuit Encounter with the East., Londres, Faber and Faber, 2011.

Malatesta, Edward J., S.J., «Alessandro Valignano Fan Li-An范禮安 (15391606) estratega da missão jesuita na China». Revista de cultura, Edição do Instituto Cultural de Macao, n. ${ }^{\circ} 21$ (II serie) (1991), 51-66.

Malek, Roman y Hofrichter, Peter, Jingjiao. The Church of the East in China 
and Central Asia, Collectanea Serica, Sankt Augustin, Institut Monumenta Serica, 2006.

Meynard, Therry S.J., The Jesuit Reading of Confucius. The First Complete Translation of the Lunyu (1687) Published in the West, Leiden-Boston, Brill, 2015.

Moran, J. F., The Japanese and the Jesuit. Alessandro Valignano in sixteenth-century Japan, Londres y Nueva York, Routledge, 1993.

Ollé, Manel, La invención de China. Percepciones y Estrategias Filipinas Respecto a China durante el Siglo XVI, Wiesbaden, Harrassowitz Verlag, 2000.

—, «The Jesuit Portrayals of China Between 1583-1590. Bulletin of PortugueseJapanese Studies, vol. 16 (2008), 45-57.

Po-Chia Hsia, Ronnie, A Jesuit in the Forbidden City: Matteo Ricci, 1552-1610, New York, Oxford University Press, 2010.

Real Academia de la Historia de Madrid, Cortes 562, ff. 519-542.

Revuelta González, Manuel, Once calas en la Historia de la Compañia de Jesús, "Servir a todos en el Señor», Madrid, Universidad Pontificia Comillas, 2006.

Ricci, Matteo, Storia dell'Introduzione del cristianesimo in Cina scritta da Matteo Ricci S. I. Nuovamente edita e ampiamente commentata col sussidio di molte fonti inedite e delle fonti cinesi da Pasquale M. D'Elia S. I., Roma, Libreria dello Stato, 1942.

Rubiés, Joan-Pau, «The Concept of Cultural Dialogue and the Jesuit Method of Accommodation: Between Idolatry and Civilization». Archivium Historicum Societatis Iesu, 74 (147) (2005), 237-280.

—, «Diálogo religioso, mediación cultural o cálculo maquiavélico? Una nueva mirada al método jesuita en Oriente, 1580-1640», Jesuitas e imperios, eds. Alexandre Coello de la Rosa, Javier Burrieza y Doris Moreno, Madrid, Sílex, 2012, 33-61.

一, Li Madou Zhongwen zhuyi ji 利瑪竇中文著譯集, Shanghai, Fudan daxue chubanshe 復旦大學出版社, 2001.

Ross, Andrew C., "Alessandro Valignano, S.J.». Missionology: An International Review, vol. XXVII, n.o 4 (1999), 510-511.

Schütte, Josef Franz, Valignano's Mission Principles for Japan. Part II: The Solution (1580-1582), Translated by John J. Coyne, S.J., St. Louis, The Institute of Jesuit Sources, 1985.

Semedo, Alvaro, Histoire universelle de la Chine, para le P. Alvarez Semedo, Portugais..., Lión, Hierosme Prost, 1667.

Spence, Jonathan D., The Memory palace of Matteo Ricci, Nueva York, Elisabeth Sifton Book, 1984.

Tolosana, Carmel Lisón, La fascinación de la diferencia. La adaptación de los jesuitas al Japón de los samuráis, 1549-1592, Madrid, Akal, 2005.

ÜÇErLer, J., Antoni, M. S.J, «Alessandro Valignano: Man, Missionary, and Writer». Alessandro Valignano, Portrait of a Jesuit, Macao, Macau Ricci Insititute, 2013. 
Valignano, Alejandro S. J., Historia del principio y progresso de la Compañia de Jesús en las Indias Orientales (1542-1564), ed. Josef Wicki, Roma, Institutum Historicum, 1944.

-, Sumario de las cosas de Japón (1583). Adiciones del Sumario de Japón (1592), ed. José Luis Alvarez-Taladriz, Monumenta Nipponica Monographs (N.9), Tokio, Sophia University, 1954.

-, Apología en la cual se responde a diversas calumnias que se escribieron contra los padres de la Compañia de Japón y de la China de Alejandro Valignano, (1598), ed. José Luis Álvarez-Taladriz, Tokio, Sophia University, 1998.

Venturi, Tacchi y S. I., Pietro, Opere Storiche del P. Matteo Ricci S. I., Vol. II, Macerata, Premiato Stabilimento Tipografico, 1911.

Wiтек, John W. S.J. y ReIs, Michel, Religion and Culture, An International Symposium Commemorating. The Fourth Century of the University College of St. Paul, Macao, Instituto Cultura de Macao, 1999. 